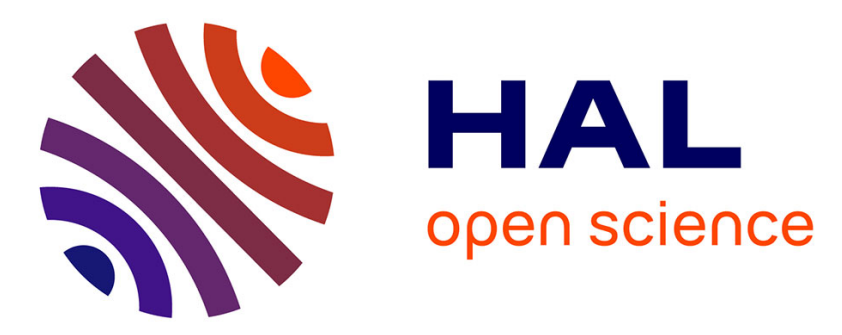

\title{
Original SF5-Containing Fluorinated Copolymers Based on Vinylidene Fluoride
}

Georges Kostov, Bruno Ameduri, Tatiana Sergeeva, W.R. Dolbier, Jr., Rudolf Winter, Gary Gard

\section{- To cite this version:}

Georges Kostov, Bruno Ameduri, Tatiana Sergeeva, W.R. Dolbier, Jr., Rudolf Winter, et al.. Original SF5-Containing Fluorinated Copolymers Based on Vinylidene Fluoride. Macromolecules, 2005, 38, pp.8316-8326. 10.1021/ma0512253 . hal-00382495

\section{HAL Id: hal-00382495 \\ https://hal.science/hal-00382495}

Submitted on 7 May 2009

HAL is a multi-disciplinary open access archive for the deposit and dissemination of scientific research documents, whether they are published or not. The documents may come from teaching and research institutions in France or abroad, or from public or private research centers.
L'archive ouverte pluridisciplinaire HAL, est destinée au dépôt et à la diffusion de documents scientifiques de niveau recherche, publiés ou non, émanant des établissements d'enseignement et de recherche français ou étrangers, des laboratoires publics ou privés. 


\title{
Original $\mathrm{SF}_{5}$-Containing Fluorinated Copolymers Based on Vinylidene Fluoride
}

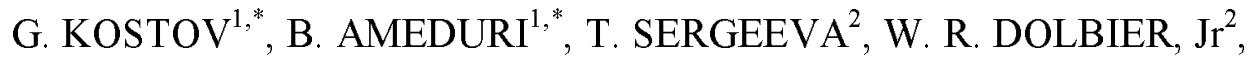 \\ R. WINTER ${ }^{3}$, G. L. GARD ${ }^{3}$
}

${ }^{1}$ Laboratory of Macromolecular Chemistry, UMR (CNRS) 5076 - Ecole Nationale Supérieure de Chimie de Montpellier - 8 rue Ecole Normale - 34296 Montpellier Cedex 05, France.

E-mail:georges.kostov@enscm.fr;bruno.ameduri@enscm.fr

${ }^{2}$ University of Florida, Department of Chemistry, PO Box 117200, Gainesville, FL, 32611-7200, USA

${ }^{3}$ Portland State University, Department of Chemistry, Portland, OR, 97207, USA

\begin{abstract}
The radical co- and terpolymerization of fluorinated monomers bearing an $\mathrm{SF}_{5}$ group, $\mathrm{XYC}=\mathrm{CZSF}_{5}$ (where $\mathrm{X}, \mathrm{Y}$ and $\mathrm{Z}$ represent either $\mathrm{H}$ or $\mathrm{F}$ atoms) with 1,1-difluoroethylene (vinylidene fluoride, $\mathrm{VDF}$ or $\mathrm{VF}_{2}$ ) and hexafluoropropene (HFP), is presented. Although these $\mathrm{SF}_{5}$ monomers do not homopolymerize under radical initiation, they do copolymerize (and terpolymerize) in solution, in the presence of radical initiators with VDF, (and with VDF and hexafluoropropylene (HFP)), hence leading to original copolymers bearing $\mathrm{SF}_{5}$ side groups. NMR characterizations and yields enabled one to compare the relative reactivities of $\mathrm{F}_{2} \mathrm{C}=\mathrm{CFSF}_{5}$, HFP, perfluoromethyl vinyl ether, and perfluoropropyl vinyl ether in the copolymerization of VDF with these fluoroolefins. The degree of fluorine substitution on the ethylenic unit of the $\mathrm{SF}_{5}$ monomers had an influence on their reactivity, their relative incorporation in the copolymers and on the molar masses of the resulting terpolymers the higher the fluorine in the $\mathrm{SF}_{5}$ monomer, the higher molecular weight. Interestingly, the greater the degree of fluorine substitution of the $\mathrm{SF}_{5}$-containing monomer, the greater the yield of the reaction. The yield also increased as the amount of initiator was increased. The relative concentrations of the comonomers in each copolymer were assessed by ${ }^{19} \mathrm{~F}$ and ${ }^{1} \mathrm{H}$ NMR spectroscopy. The thermal properties (thermal stability and glass transition temperature) of these resulting $\mathrm{SF}_{5}$-containing fluoropolymers were also examined.
\end{abstract}




\section{INTRODUCTION}

Fluoropolymers are of great interest because of their unique combination of outstanding properties ${ }^{1}$ such as chemical inertness (to acids, bases, solvents and petroleum), low dielectric constants and dissipation factors, low water absorptivities, excellent weatherabilities and very interesting surface properties. Hence, these high value added products can find relevant applications in many fields of high technology: aeronautics ${ }^{2}$, microelectronics, engineering, chemical and automotive industries, optics $^{3}$, textile finishing ${ }^{4}$ and military use ${ }^{5}$. The specific properties (adhesion, solubility, curability, surface properties, good hydrophilicity, heat or chemical resistance) of a fluoropolymer are determined by the nature of the specific functional group that is present in the lateral position of the copolymer backbone. The synthesis of fluoropolymers can be realized by copolymerization of fluoroalkenes with other fluorinated or nonhalogenated monomers. In contrast to such copolymers, fluorinated homopolymers (e.g., polyvinylidene fluoride, polytetrafluoroethylene or polychlorotrifluoroethylene) exhibit a high crystallinity rate that induces high costs in the processing at the molten state, poor solubility in organic common solvents and difficult crosslinking.

Among these fluorinated copolymers, those incorporating vinylidene fluoride (VDF) monomeric units are of particular interest, because they can be either thermoplastics ${ }^{6}$, or elastomers ${ }^{7}$, or thermoplastic elastomers ${ }^{1 \mathrm{~d}, 8}$. Usually, such fluoropolymers can be synthesized by radical copolymerization of VDF with other fluoroalkenes leading to statistical copolymers ${ }^{7,9}$ except for copolymers prepared from hexafluoroisobutylene ${ }^{10}$ (commercialized by the Allied Company under the $\mathrm{CMX}^{\circledR}$ trade mark), methyl trifluoroacrylate ${ }^{11}$ and $\alpha$-trifluoromethyl acrylic acid ${ }^{12}$ which are unexpected alternating copolymers. In fact, VDF has been copolymerized with various fluorinated monomers with the resulting copolymers bearing functions such as: hydroxy ${ }^{13}$, acetoxy ${ }^{13,14}$, thioacetoxy ${ }^{15}$, sulfonyl fluoride ${ }^{16}$, nitrile ${ }^{17}$, bromine ${ }^{18}$ or a perfluoroalkyl group ${ }^{19}$.

Interestingly, monomers bearing the $\mathrm{SF}_{5}$-group have led to a number of materials that can be used as high-performance lubricants and optical materials, water repellent and oil-resistant sealants, antifoaming agents, surface-active agents, and protective surface coatings ${ }^{20-23}$. Recent studies have prepared not only $\mathrm{SF}_{5}$-polyfluoroalkylacrylates ${ }^{24}, \mathrm{SF}_{5}$-polyfluoroalkylsiloxanes ${ }^{25}, \mathrm{SF}_{5}$ polyfluoroalkylepoxides ${ }^{26}$ but also aromatic polymers that include polyimides containing the $\mathrm{SF}_{5}\left(\mathrm{CF}_{2}\right)_{n} \mathrm{C}_{6} \mathrm{H}_{3}$ - groups $(\mathrm{n}=0,2)^{26,27}$, polyacrylate and polystyrene containing the $\mathrm{SF}_{5} \mathrm{CF}_{2} \mathrm{CF}_{2}$-group 28. Additional properties brought about by the $\mathrm{SF}_{5}$-group include low wettability, low refractive index, low surface energy, high dielectric strength, high chemical and thermal stability. The use of $\mathrm{SF}_{5}$ monomers has resulted in the preparation of the first organic superconductor with an organic anion ${ }^{29}$, 
the first $\mathrm{SF}_{5}$-organic metals/organic semiconductors ${ }^{30}$, the first $\mathrm{SF}_{5}$-containing ionic liquids ${ }^{31}$ and the preparation of novel liquid crystals ${ }^{32}$

Different $\mathrm{SF}_{5}$ - containing copolymers (acrylates, silicones, epoxides) exhibit nonstoichiometric enrichment of the film surface with fluorinated monomers bearing $\mathrm{SF}_{5}$ groups.

Prior to our studies, in 1969 and 1974, Banks et al. ${ }^{33-34}$ reported the preparation of $\mathrm{SF}_{5}-$ containing polymers with VDF and HFP in emulsion using an aqueous redox initiation system and perfluorooctanoic acid. However, no data was supplied about the copolymer compositions. In addition, the microstructure, the molecular weight and $\mathrm{Tg}$ values of copolymers obtained were not described. We considered it to be worthwhile to revisit that copolymerization system and to provide characterization of the binary and ternary systems with different $\mathrm{SF}_{5}$ comonomers (hydrogenated and perfluorinated).

Hence, the objective of this paper deals with the radical binary and terpolymerization of different $\mathrm{SF}_{5}$ containing monomers, their reactivity with VDF and HFP and the detailed characterization of the copolymers obtained.

\section{EXPERIMENTAL}

\section{Materials}

Vinylidene fluoride (VDF), hexafluoropropene (HFP) and 1,1,1,3,3-pentafluorobutane (kindly provided by Solvay Solexis S.A., Tavaux, France and Brussels, Belgium), di(tert-butylperoxide, DTBP (Aldrich Chimie, 38299 Saint Quentin-Fallavier, France). They were used as supplied. Acetonitrile, dimethylsulfoxyde of analytical grade (Aldrich Chimie, 38299 Saint Quentin-Fallavier, France), were distilled over calcium hydride prior to use.

\section{Analysis}

The compositions of the co- and terpolymers (the molar contents of VDF, HFP, and $\mathrm{SF}_{5}$-containing monomers) were determined by ${ }^{19} \mathrm{~F}$ and ${ }^{1} \mathrm{H}$ NMR spectroscopy. The NMR spectra were recorded on Bruker AC 200 and AC 250 instruments, using deuterated acetone as the solvent and TMS (or CFCl $\mathrm{C}_{3}$ ) as the references for ${ }^{1} \mathrm{H}$ ( or ${ }^{19} \mathrm{~F}$ ) nuclei. Coupling constants and chemical shifts are given in $\mathrm{Hz}$ and ppm, respectively. The experimental conditions for ${ }^{1} \mathrm{H}$ ( or ${ }^{19} \mathrm{~F}$ ) NMR spectra were the following: flip angle $90^{\circ}$ (or $30^{\circ}$ ), acquisition time $4.5 \mathrm{~s}$ (or $0.7 \mathrm{~s}$ ), pulse delay $2 \mathrm{~s}$ (or $5 \mathrm{~s}$ ), number of scans 16 (or 64), and a pulse width of $5 \mu \mathrm{s}$ for ${ }^{19} \mathrm{~F}$ NMR.

Differential scanning calorimetry (DSC) measurements were conducted using a Perkin-Elmer Pyris 1 instrument connected to a micro-computer. The apparatus was calibrated with indium and n-decane. After its insertion into the DSC apparatus, the sample was initially cooled to $-105^{\circ} \mathrm{C}$ for $15 \min$. 
Then, the first scan was made at a heating rate of $40^{\circ} \mathrm{C} \cdot \mathrm{min}^{-1}$ up to $80^{\circ} \mathrm{C}$, where it remained for $2 \mathrm{~min}$. It was then cooled to $-105^{\circ} \mathrm{C}$ at a rate of $320^{\circ} \mathrm{C} \cdot \mathrm{min}^{-1}$ and left for $10 \mathrm{~min}$ at that temperature before a second scan was started at a heating rate of $20^{\circ} \mathrm{C} \cdot \mathrm{min}^{-1}$. Finally, another cycle was performed and a third scan at a heating rate of $20^{\circ} \mathrm{C} \cdot \mathrm{min}^{-1}$ was initiated, giving the values of $\mathrm{Tg}$ reported herein, taken at the half-height of the heat capacity jump of the glass transition.

Thermogravimetric analyses were performed with a Texas Instrument TGA 51-133 apparatus in air at a heating rate of $10^{\circ} \mathrm{C} \cdot \mathrm{min}^{-1}$ from room temperature up to a maximum of $600{ }^{\circ} \mathrm{C}$.

Gel Permeation Exclusion Chromatography (GPC) or Size Exclusion Chromatography (SEC) was carried out in tetrahydrofuran at $30^{\circ} \mathrm{C}$, at a flow rate of $0.8 \mathrm{~mL} / \mathrm{min}$, by means of a Spectra Physics Winner Station, a Waters Associate R 401 differential refractometer and a set of four columns

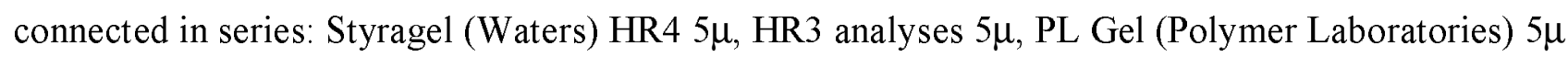
$100 \AA$ A. Monodispersed ( PMMA) standards were used for calibration. Aliquots were sampled from the reaction medium, diluted with tetrahydrofuran up to a known concentration $\left(C_{p, t}\right)$ ca. $4 \%$ wt.- $\%$, filtered through a $20 \mu \mathrm{m}$ PTFE Chromafil Membrane and finally analyzed by GPC under the conditions described above.

\section{Synthesis of $\mathrm{SF}_{\mathbf{5}}$-containing monomers}

1-chloro-2-pentafluorosulfanylethane $\left(\mathrm{ClCH}_{2} \mathrm{CH}_{2} \mathbf{S F}_{5}\right)$. A $50 \mathrm{~mL}$ three-necked flask containing $30 \mathrm{~mL}$ of methylene chloride and bearing a dry ice condenser was cooled to $-60{ }^{\circ} \mathrm{C}$, and ethylene was bubbled vigorously through the solution for a five minutes, after which $3.2 \mathrm{~g}(0.020 \mathrm{~mol})$ of $\mathrm{SF}_{5} \mathrm{Cl}$ was bubbled into the mixture. Triethylborane $(1 \mathrm{~mL})$ was then added dropwise to the mixture, with stirring, and the bubbling of ethylene was recommenced for another 5 minutes. After $1 \mathrm{~h}$ at $-60{ }^{\circ} \mathrm{C}$, the solution was allowed to warm to $-30{ }^{\circ} \mathrm{C}$, where it was maintained for another $2 \mathrm{~h}$. The solvent was removed by distillation to give $2.5 \mathrm{~g}$ (yield: $65 \%$ ) of a residue that was essentially pure 1chloro-2-pentafluorosulfanylethane, which was used directly in the next reaction. Bp: $92-93{ }^{\circ} \mathrm{C} ;{ }^{1} \mathrm{H}$ NMR: $\delta 4.15-3.85(\mathrm{~m}) ;{ }^{19} \mathrm{~F}$ NMR: $\delta 81.57(\mathrm{q}, 1 \mathrm{~F}), 64.92(\mathrm{~d}, 4 \mathrm{~F})$.

Pentafluorosulfanylethene, $\mathbf{M}-\mathbf{I}\left(\mathbf{H}_{2} \mathbf{C}=\mathbf{C H S F}_{5}\right)$. To $3.5 \mathrm{~g} \mathrm{KOH}$ in $4 \mathrm{~mL}$ of water was added $10.5 \mathrm{~mL}$ of isopropanol in a $50 \mathrm{~mL}$ three-necked flask equipped with an addition funnel and a reflux condenser connected to a trap cooled by a dry ice/acetone bath. The solution was brought to reflux and then $4.5 \mathrm{~g}(0.024 \mathrm{~mol})$ of the 1-chloro-2-pentafluorosulfanylethane was added dropwise. The mixture was refluxed for $2 \mathrm{~h}$, with $2.9 \mathrm{~g}$ (yield: $79 \%$ ) of the desired product being collected in the cooled trap: ${ }^{1} \mathrm{H}$ NMR, $\delta 5.74(\mathrm{~m}, 1 \mathrm{H}), 6.01(\mathrm{~d}, \mathrm{~J}=15 \mathrm{hz}, 1 \mathrm{H}), 6.68(\mathrm{~m}, 1 \mathrm{H}) ;{ }^{19} \mathrm{~F}$ NMR: $\mathrm{AB}_{4}$ system, $\delta$ 81.5 (pent, $1 \mathrm{~F})$ and $59.7(\mathrm{~d}, 4 \mathrm{~F}), \mathrm{J}_{\mathrm{AB}}=146 \mathrm{~Hz}^{35}$. 
1-Chloro-1,1-difluoro-2-pentafluorosulfanylethane $\left(\mathrm{ClCF}_{2} \mathrm{CH}_{2} \mathbf{S F}_{5}\right)$. To a $50 \mathrm{~mL}$ threenecked flash bearing a dry ice condenser and cooled to $-50{ }^{\circ} \mathrm{C}$ was condensed $20 \mathrm{~mL}$ of $\mathrm{ClCF}_{2} \mathrm{CH}_{3}$ (Forane 142b) and $4.4 \mathrm{~g}$ (4 equiv) of $\mathrm{CF}_{2}=\mathrm{CH}_{2}$ (VDF). To this mixture was added $2.7 \mathrm{~g}(0.017 \mathrm{~mol})$ of $\mathrm{SF}_{5} \mathrm{Cl}$. Then $1.5 \mathrm{~mL}$ of $\mathrm{Et}_{3} \mathrm{~B}$ was added to the mixture drop wise and the mixture stirred at -20 to $30{ }^{\circ} \mathrm{C}$ for $3 \mathrm{~h}$, after which the flask was stoppered and allowed to stand at $-20{ }^{\circ} \mathrm{C}$ for three days. Then the fluorinated solvent was evaporated, leaving $1.5 \mathrm{~g}$ (yield: $40 \%$ ) of almost pure product, 1-chloro-1,1difluoro-2-pentafluorosulfanylethane, which was used directly in the next reaction. $\mathrm{Bp} 70{ }^{\circ} \mathrm{C} ;{ }^{1} \mathrm{H}$ NMR: $\delta 4.4-4.2(\mathrm{~m}) ;{ }^{19} \mathrm{~F}$ NMR: $\delta 77.04(\mathrm{q}, 1 \mathrm{~F}), 70.06(\mathrm{~d}, 4 \mathrm{~F}),-55.35(\mathrm{~s}, 2 \mathrm{~F})$.

1,1-Difluoro-2-pentafluorosulfanylethene, $\mathrm{M}-\mathrm{II}\left(\mathrm{F}_{2} \mathbf{C}=\mathbf{C H S F}_{5}\right)$. A 50-ml round-bottom flask equipped with a magnetic stirrer and a $20-\mathrm{cm}$ reflux condenser that was connected to a cold trap ($78^{\circ} \mathrm{C}$ ) was charged with an aqueous potassium hydroxide solution (13 $\mathrm{g}, 42.5 \%$ by weight). 1-Chloro1,1-difluoro-2-pentafluorosulfanylethane $(4.4 \mathrm{~g}, 19 \mathrm{mmol})$ was added at room temperature to the solution. The mixture was slowly heated to $100{ }^{\circ} \mathrm{C}$. Heating was continued for $2 \mathrm{hrs}$ with simultaneous collection of the product $\mathbf{M}-\mathrm{II}$ in a cold trap, $2.1 \mathrm{~g}(13 \mathrm{mmol}$, yield: $70 \%)$. Bp $26{ }^{\circ} \mathrm{C} ;{ }^{1} \mathrm{H}$ NMR: $\delta 5.7$ (m) ; ${ }^{19}$ F NMR: $\delta 78.89\left(\mathrm{~m}, 1 \mathrm{~F}, \mathrm{SF}_{5}\right), 72.78\left(\mathrm{~d}, 4 \mathrm{~F}, \mathrm{SF}_{5}\right),-65.80(\mathrm{~m}, 1 \mathrm{~F}),-83.96(\mathrm{~m}, 1 \mathrm{~F}){ }^{36-38}$.

\section{1,1,2-Trifluoro-2-pentafluorosulfanylethene, $\mathrm{SF}_{5} \mathrm{CF}=\mathrm{CF}_{2},(\mathrm{M}-\mathrm{III})$ was prepared from} $\mathrm{SF}_{5} \mathrm{CHFCF}_{2} \mathrm{Br}$ as described in the literature ${ }^{38}$. The purity of the starting material was checked via IR and NMR spectroscopy.

IR $\left(\mathrm{cm}^{-1}\right): 1782(\mathrm{~s}, \mathrm{C}=\mathrm{C}), 1351(\mathrm{~s}), 1246(\mathrm{~s}), 1089(\mathrm{~m}), 898(\mathrm{vs}), 862(\mathrm{vs}), 706(\mathrm{~m}), 654(\mathrm{wm}), 613(\mathrm{~s})$. The absorptions at 898 and $862 \mathrm{~cm}^{-1}$ are due to S-F stretching while that at $613 \mathrm{~cm}^{-1}$ is due to one of the $\mathrm{SF}_{5}$-deformation modes.

NMR $\left(\mathrm{CDCl}_{3}, \mathrm{CFCl}_{3}\right): 69.7$ (nine-line pattern, 1F, $\left.\mathrm{SF}_{5}\right) ; 59.0\left(\mathrm{~d}, 4 \mathrm{~F}, \mathrm{SF}_{5}\right) ;-163(\mathrm{~m}, 1 \mathrm{~F}, \mathrm{CF}=)$; -99.5 $\left(\mathrm{m}, 2 \mathrm{~F},=\mathrm{CF}_{2}\right)$.

\section{Copolymerization}

The batch copolymerizations of VDF with $\mathrm{CF}_{2}=\mathrm{CFRf}$ were performed in thick borosilicate Carius tubes (length $130 \mathrm{~mm}$, internal diameter $10 \mathrm{~mm}$, thickness $2.5 \mathrm{~mm}$; for a total volume of 8 $\mathrm{cm}^{3}$ ). After the introduction of the initiator (di tert-butyl peroxide $\sim 1.0 \mathrm{~mol} \%$ versus the monomer quantities) and acetonitrile (1.5-2.0 g), the tube was connected to a manifold and then cooled with liquid nitrogen. After five freeze - thaw cycles, the appropriate gas quantities were trapped in the tube cooled in liquid nitrogen under $20 \mathrm{~mm} \mathrm{Hg}$. To introduce the targeted VDF quantities, a previous calibration was made to link the gas pressure (bars) to the introduced weight (grams) (for example, a 
difference of pressure of 0.66 bar represents $1.00 \mathrm{~g}$ of VDF). The tube was sealed while immersed in liquid nitrogen and then stirred at the chosen temperature $\left(140{ }^{\circ} \mathrm{C}\right)$ for the required time $(0.5$ hours was chosen for carrying out the process of radical copolymerization). After reaction, the total product mixture was analyzed by ${ }^{19} \mathrm{~F}$ NMR and ${ }^{1} \mathrm{H}$ NMR. Then, the copolymers were precipitated from cold pentane and dried until constant weight was reached.

Batch terpolymerizations of VDF (with HFP) and the $\mathrm{SF}_{5}$-containing monomers were performed in a $160 \mathrm{ml}$ Hastelloy (HC 276) autoclave, equipped with an inlet valve, a manometer, and a rupture disk. The autoclave was purged with 20 bars of nitrogen pressure and left closed for 20 minutes to test for leakage. After releasing the pressure, a $20 \mathrm{~mm} \mathrm{Hg}$ vacuum was operated for $15 \mathrm{~min}$, and then the initiator di(tert-butylperoxide), $\mathrm{SF}_{5}$ monomers, and 1,1,1,3,3-pentafluorobutane were introduced successively via a funnel tightly connected to the introduction valve. Next, VDF and HFP were respectively introduced by double weighing. The autoclave was then heated at $143{ }^{\circ} \mathrm{C}$ for 5 hours. After reaction, the vessel was cooled to room temperature and then put in an ice bath. The non-reacted monomers were separated and the conversion vs. monomers was determined. Then, the solvent was evaporated, the co- or terpolymer was precipitated from cold pentane and the total product mixture was dried at $0.1 \mathrm{~mm} \mathrm{Hg}$ at $40^{\circ} \mathrm{C}$ for $15 \mathrm{hrs}$ (to constant weight).

Highly viscous or rubber-like polymers were obtained.

\section{RESULTS AND DISCUSSION}

\section{(I) Synthesis of Monomers containing SF5 (SF5M)}

Monomers M-I and M-II were prepared in a manner similar to those described in the literature, but using our new $\mathrm{Et}_{3} \mathrm{~B}$-initiation methodology ${ }^{39}$ to add $\mathrm{SF}_{5} \mathrm{Cl}$ to ethylene and VDF, respectively.
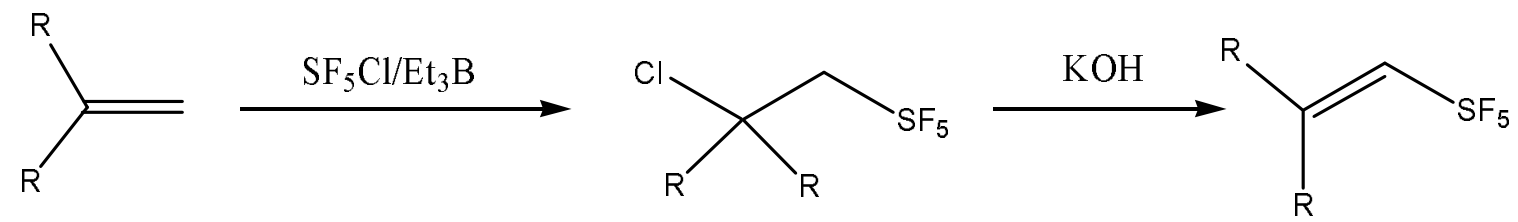

$$
\begin{aligned}
& \text { M-I, } R=H \\
& \text { M-II, } R=F
\end{aligned}
$$

The reaction of $\mathrm{SF}_{5} \mathrm{Cl}$ with ethylene proceeded smoothly in dichloromethane at $-30^{\circ}$ to $-20^{\circ} \mathrm{C}$ over $2 \mathrm{hrs}$ furnishing 1-chloro-2-pentafluorosulfanylethane in good yield, but the synthesis of 1chloro-1,1-difluoro-2-pentafluorosulfanylethane proved to be more difficult. As pointed out by Case et al. ${ }^{40}$, reactions of $\mathrm{SF}_{5} \mathrm{Cl}$ with fluorocarbon olefins do not take place as easily as those with 
hydrocarbon olefins. Thus, significantly harsher conditions were required for the reaction with VDF to occur. Only trace amounts of product were obtained after treatment of VDF with $\mathrm{SF}_{5} \mathrm{Cl}$ in dichloromethane or pentane. On the other hand, when the reaction was carried out in $\mathrm{ClCF}_{2} \mathrm{CH}_{3}$ (Forane 142B) as a solvent, it was possible to increase the yield up to 70-80\%. Neat $\mathrm{Et}_{3} \mathrm{~B}$ instead of its $1 \mathrm{M}$ solution in hexanes was used for these reactions, which allowed us to avoid a step of solvent removal. Since the boiling point of $\mathrm{ClCF}_{2} \mathrm{CH}_{3}$ is only $-10^{\circ} \mathrm{C}$, essentially pure products were obtained by simply warming the reaction to room temperature. These chloro, pentafluorosulfanylethane intermediates were used in the next step without further purification.

For the synthesis of pentafluorosulfanyl ethylene M-I, a method developed by Wessel et al. ${ }^{35}$ was adopted. Treatment of the chloro precursor with $\mathrm{KOH} / \mathrm{H}_{2} \mathrm{O} / \mathrm{i}-\mathrm{PrOH}$ allowed preparation of monomer M-I in high yields.

When we attempted to use this method for preparation of $\mathbf{M}-\mathbf{I I}$, a messy mixture containing the product as well as its decomposition products was obtained. Winter and Gard successfully prepared M-II starting from 1-bromo-1,1-difluoro-2-pentafluorosulfanylethane ${ }^{37}$. Fortunately, the chloro precursor underwent dehydrochlorination smoothly under the same conditions with no formation of decomposition products being observed upon its treatment with $42.5 \% \mathrm{KOH}$ solution.

M-III monomer $\left(\mathrm{F}_{2} \mathrm{C}=\mathrm{CFSF}_{5}\right)$ was obtained from the radical addition of $\mathrm{BrSF}_{5}$ onto trifluoroethylene followed by a dehydrobromination as reported in a previous work ${ }^{38,39}$

\section{(II). Radical copolymerization of $\mathrm{SF}_{5}$-containing monomers with VDF and HFP (II-1)Radical copolymerization of $\mathrm{F}_{2} \underline{\mathrm{C}=\mathrm{CFSF}_{5}} \underline{\text { with VDF }}$}

Initially, the radical homopolymerization of $\mathrm{F}_{2} \mathrm{C}=\mathrm{CFSF}_{5}$ was attempted under classic conditions of homopolymerization starting from a [di tert-butyl peroxide, $\mathrm{DTBP}]_{0}$ to $\left[\mathrm{F}_{2} \mathrm{C}=\mathrm{CFSF}_{5}\right]_{0}$ molar ratio of 2 $\mathrm{mol} \%, 5.0 \mathrm{~g}$ (0.024 moles) of $\mathrm{CF}_{2}=\mathrm{CFSF}_{5}$, solvent $1,1,1,3,3$-pentafluorobutane ( $70 \mathrm{wt} \%$ ), temperature $143{ }^{\circ} \mathrm{C}$ and reaction time $5 \mathrm{hrs}$. It was noted that no reaction occurred, probably because of the bulky $\mathrm{SF}_{5}$ substituent which, as in the case of HFP, PPVE, PMVE or PFP prevents these fluoromonomers from undergoing homopolymerizations.

Then, the radical copolymerization of VDF with $\mathrm{F}_{2} \mathrm{C}=\mathrm{CFSF}_{5}$ was carried out and compared to those of VDF with hexafluoropropene (HFP), VDF and perfluoromethyl vinyl ether (PMVE) and VDF with perfluoropropyl vinyl ether (PPVE). For each couple, three different copolymerizations were carried out using VDF mol. percentages of ca. 20, 50 and 75\% under the same conditions of batch (initiator ditert-butyl peroxide in 1,1,1,3,3-pentafluorobutane as the solvent). Because of the high volatilities of $\mathrm{VDF}$ and $\mathrm{SF}_{5}$-containing monomers, the precise assessement of monomer conversions was difficult to obtain. Nevertheless, the monomer conversions were established to be less than $10 \mathrm{wt} \%$. 
Both comonomeric units in each of the copolymers were assessed by ${ }^{19} \mathrm{~F}$ NMR spectroscopy.
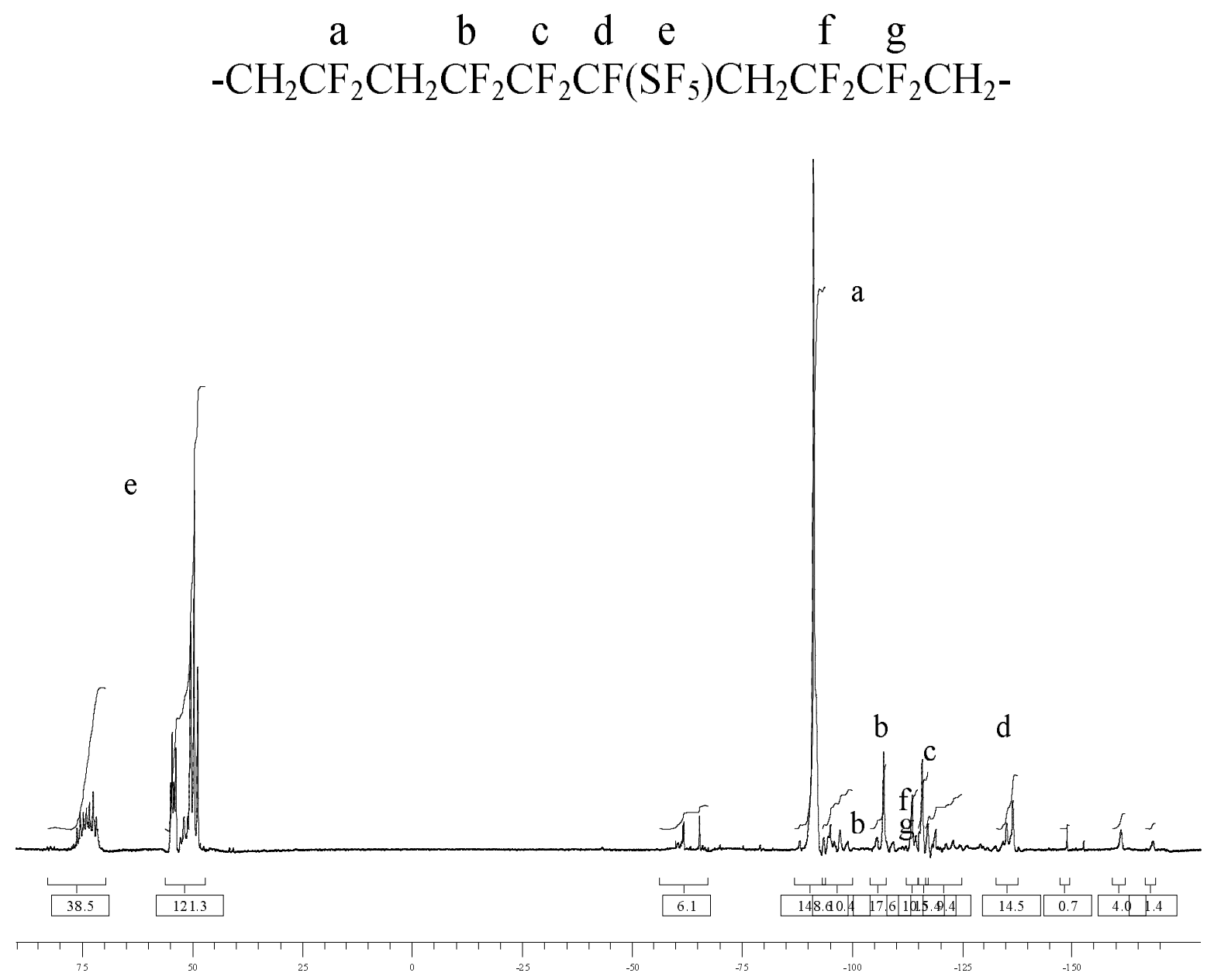

Fig. $1{ }^{19} \mathrm{~F}$ NMR spectrum of $\mathrm{VDF} / \mathrm{CF}_{2}=\mathrm{CF}\left(\mathrm{SF}_{5}\right)$ copolymer at $70 / 30 \mathrm{~mol} \%$ monomer ratio in the feed

Those of poly(VDF-co-HFP) ${ }^{41}$, poly(VDF-co-PMVE) ${ }^{19 b, 42}$ and poly(VDF-co-PPVE) ${ }^{19 b, 42}$ copolymers had been previously characterized by ${ }^{19} \mathrm{~F}$ NMR while that of poly(VDF-co-SF $\left.\mathrm{M}_{5}\right)$ copolymers has never been reported in the literature Table 1 . For example, Figure 1 represents the ${ }^{19} \mathrm{~F}$ NMR of the copolymers prepared by radical copolymerization of VDF and $\mathrm{SF}_{5}$-monomer III $\left(\mathrm{CF}_{2}=\mathrm{CFSF}_{5}\right)$ starting from an initial feed percentage of VDF/M-III $=70 / 30$. This spectrum shows a peak centered at about $-91.1 \mathrm{ppm}$ (noted $\mathrm{I}_{-91.1}$ ) characteristic of the difluoromethylene groups of the head-to-tail VDF chaining (i.e., normal VDF addition). Furthermore, a series of other signals centered at -94.9 (noted $\mathrm{I}_{-94}$ ), -113.7 (noted $\mathrm{I}_{-113.7}$ ) and -115.7 (noted $\mathrm{I}_{-115.7}$ ) ppm can be assigned to the $\mathrm{CF}_{2}$ groups in $\left(\mathrm{CH}_{2}-\mathrm{CF}_{2}\right)-\left(\mathrm{CF}_{2}-\mathrm{CH}_{2}\right)-\left(\mathrm{CH}_{2}-\mathrm{CF}_{2}\right)-\left(\mathrm{CH}_{2}-\mathrm{CF}_{2}\right)$; -( $\left.\mathrm{CH}_{2}-\mathrm{CF}_{2}\right)-\left(\mathrm{CF}_{2}-\mathrm{CH}_{2}\right)-\left(\mathrm{CF}_{2}-\mathrm{CH}_{2}\right)-$; $\left(\mathrm{CH}_{2}-\mathrm{CF}_{2}\right)-\left(\mathrm{CF}_{2}-\mathrm{CH}_{2}\right)-\left(\mathrm{CH}_{2}-\mathrm{CF}_{2}\right)$ sequences, respectively, and correspond to the reverse VDF addition 
(i.e., head-to-head addition) ${ }^{43}$ as noted for the chemical shifts observed for ${ }^{19} \mathrm{~F} \mathrm{NMR}$ spectra of poly(VDF-co-HFP) ${ }^{41}$ or poly(VDF-co-PVME) ${ }^{42}$. The multiplet signals from +75 to $+50 \mathrm{ppm}$ are ideally an $\mathrm{AB}_{4}$ system and are assigned to the five fluorine atoms in the $\mathrm{SF}_{5}$ groups; the first one was a nine-line pattern, each line split into a triplet, and the second one was a skewed doublet of a pentet. The difluoromethylene group of $\mathrm{VDF}$ adjacent to $\mathrm{CF}_{2} \mathrm{CF}\left(\mathrm{SF}_{5}\right)$ leads to a signal centered at $-109.8 \mathrm{ppm}$ while those centered at -118.8 and $-136.7 \mathrm{ppm}$ are related to the $-\mathrm{CF}_{2}$ and $-\mathrm{CF}$ groups, respectively, deriving from the perfluorovinyl group of the M-III monomer (Table 2). The microstructure of the copolymers was assessed by $\mathrm{mol}_{\%} \mathrm{SF}_{5}=\left(\mathrm{I}_{+50}\right.$ to +75$) / 5$ for the multiplet centered at $-135 \mathrm{ppm}$ for $\mathrm{CF}\left(\mathrm{SF}_{5}\right)$ fluorine atom. Indeed, both fluorine atoms in the difluoromethylene group adjacent to $\mathrm{CF}\left(\mathrm{SF}_{5}\right)$ were anisochronous, hence leading to an $\mathrm{AB}$ system. This arises from the bulky $-\mathrm{SF}_{5}$ group which stiffens the molecule as we had noted in $\mathrm{C}_{4} \mathrm{~F}_{9} \mathrm{CF}_{2} \mathrm{CF}\left(\mathrm{CF}_{3}\right) \mathrm{I}$ obtained by telomerization of HFP with $\mathrm{C}_{4} \mathrm{~F}_{9} \mathrm{I}^{45}$.In that monoadduct containing a bulky iodine, the central $\mathrm{CF}_{2}$ group yielded an $\mathrm{AB}$ system. This $\mathrm{AB}$ system was also noted on $\mathrm{CF}_{2}$ of VDF adjacent to $-\mathrm{CF}_{2} \mathrm{CF}\left(\mathrm{CF}_{3}\right)$ as in the case of $\mathrm{C}_{3} \mathrm{~F}_{7} \mathrm{CF}_{2} \mathrm{CF}\left(\mathrm{CF}_{3}\right) \mathrm{I}$. Because of the overlapping of different signals in that region it was difficult to assess the mol \% $\mathrm{CF}_{5} \mathrm{M}$ from $\delta \mathrm{CF}_{2}$ atoms. Interestingly, no doublet of multiplets centered at -114.8 ppm corresponding to $-\mathrm{CH}_{2} \mathrm{CF}_{2} \mathrm{H}$ end-group was observed, proving the absence of transfer reaction $41,43,44,45$. The mol percentage of VDF in the copolymer was assessed from the following formulae taking into account that integrals of signals centered at -113 and $-116 \mathrm{ppm}$ are the same with some overlapping of those centered at -116 and $-118.8 \mathrm{ppm}$ :

$$
\text { Mol. \% VDF= }\left[\mathrm{I}_{-91}+\mathrm{I}_{-94}+\mathrm{I}_{-107}+2 \mathrm{I}_{-113.7}\right] /\left[\mathrm{I}_{-91}+\mathrm{I}_{-94}+\mathrm{I}_{-107}+2 \mathrm{I}_{-113.7}\right]+2 \mathrm{I}_{-136.7}
$$

${ }^{1} \mathrm{H}$ NMR spectrum (Fig.2) exhibits one multiplet signal centered at $3.0 \mathrm{ppm}$ assigned to the $-\mathrm{CH}_{2}$ protons of normal VDF units and traces of signals at 2.3-2.4 ppm that can be related to the $\mathrm{CH}_{2}$ groups in the reverse structure of VDF (or tail to tail addition) ${ }^{41,43}$. Interestingly, no triplet of triplets is seen, which would be characteristic of $-\mathrm{CH}_{2} \mathrm{CF}_{2} \mathrm{H}$ arising from an $\mathrm{H}$-transfer from solvent or polymer.

Table 1 summarizes the results obtained from the four different series of radical copolymerization involving VDF. It is observed that comparing all cases, the $\mathrm{SF}_{5}$ monomer is the least reactive and the decreasing reactivity series is suggested:

$\mathrm{HFP}>\mathrm{PPVE}>\mathrm{PMVE}>\mathrm{SF}_{5} \mathrm{M}$

That low reactivity of $\mathrm{SF}_{5} \mathrm{M}$ may arise from both the bulky electron withdrawing $\mathrm{SF}_{5}$ groups and the delocalization of the electron in the radical $\sim \mathrm{CF}_{2} \mathrm{C} \cdot \mathrm{F}\left(\mathrm{SF}_{5}\right)$ terminal groups. This observation results in low molecular weight copolymers in the range of $1700-5400 \mathrm{~g} / \mathrm{mol}$. From a mechanistic point of view, when DTBP is thermally decomposed two different radicals can be produced as follows: 


$$
\text { tert-BuO-Otert-Bu } \rightarrow 2 \text { tert-BuO } \rightarrow 2^{\circ} \mathrm{CH}_{3}+2 \mathrm{CH}_{3} \mathrm{COCH}_{3}\left(\mathrm{~T}>100^{\circ} \mathrm{C}\right)
$$

It is assumed that tert-BuO ${ }^{\circ}$ undergoes a thermal fragmentation $\left(\mathrm{T}>100^{\circ} \mathrm{C}\right)$ to generate ${ }^{\circ} \mathrm{CH}_{3}{ }^{43 d}$. The radicals produced can react onto both sides of VDF in a non-regioselective manner:

$$
\begin{gathered}
\mathrm{R}^{\bullet}+\mathrm{H}_{2} \mathrm{C}=\mathrm{CF}_{2} \rightarrow \mathrm{RCH}_{2} \mathrm{C}^{\bullet} \mathrm{F}_{2}+\mathrm{RCF}_{2} \mathrm{C}^{\bullet} \mathrm{H}_{2} \\
\mathrm{R}: \mathrm{CH}_{3} \text {, tert-BuO }
\end{gathered}
$$

a $\quad$ b c

\section{$-\mathrm{CH}_{2} \mathrm{CF}_{2} \mathrm{CH}_{2} \mathrm{CF}_{2} \mathrm{CF}_{2} \mathrm{CF}\left(\mathrm{SF}_{5}\right) \mathrm{CF}_{2} \mathrm{CH}_{2} \mathrm{CH}_{2} \mathrm{CF}_{2}-$}

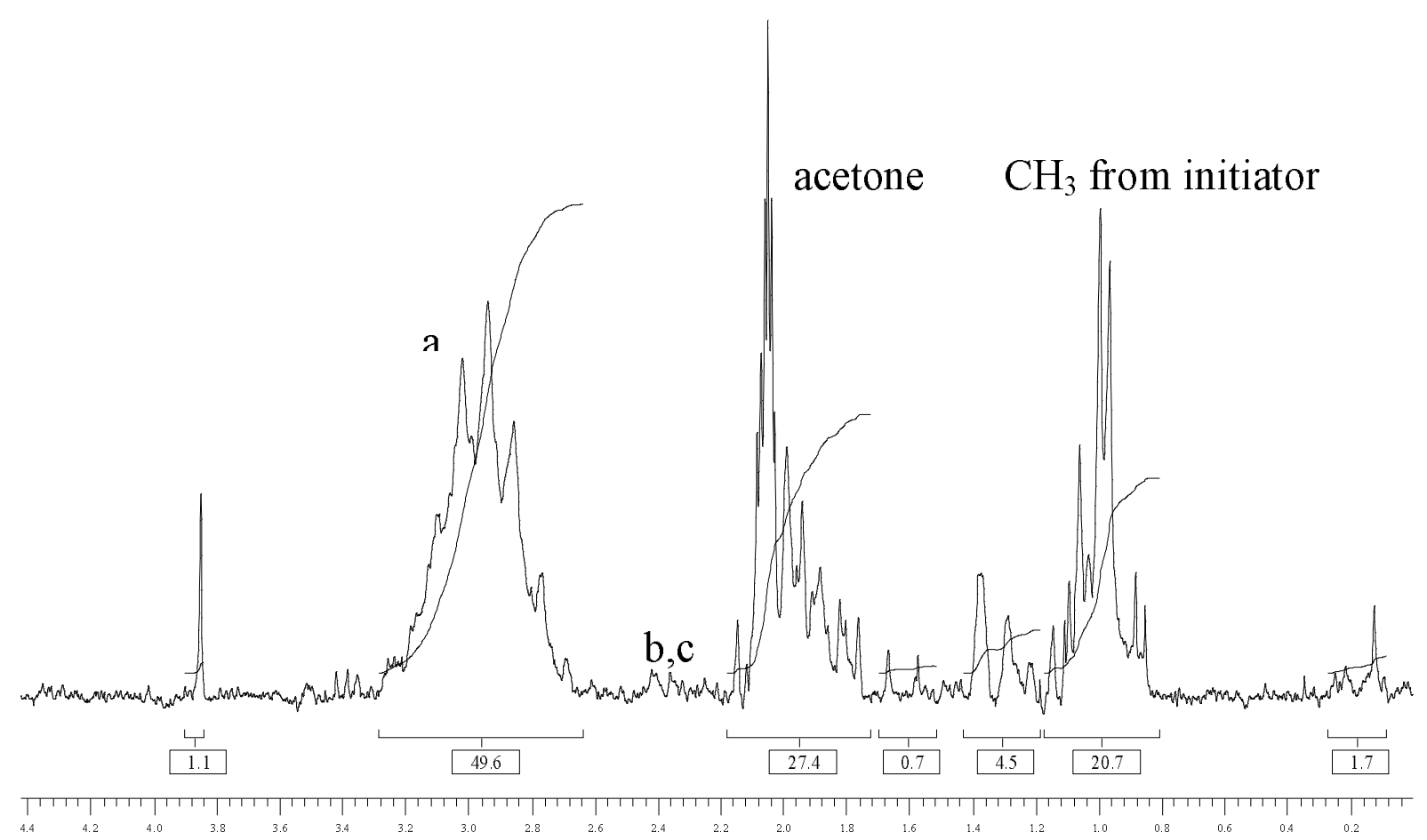

Fig. $2{ }^{1} \mathrm{H}$ NMR spectrum of $\mathrm{VDF} / \mathrm{CF}_{2}=\mathrm{CF}\left(\mathrm{SF}_{5}\right)$ copolymer at $70 / 30 \mathrm{~mol} \%$ monomer ratio in the feed.

${ }^{1} \mathrm{H}$ NMR can evidence these hydrogenated end-groups as follows:

$\mathrm{CH}_{3} \mathrm{CH}_{2} \mathrm{CF}$ - at $1.2 \mathrm{ppm}, \mathrm{CH}_{3} \mathrm{CF}_{2} \mathrm{CH}_{2}-$ at $11.8 \mathrm{ppm},\left(\mathrm{CH}_{3}\right)_{3} \mathrm{C}-\mathrm{OCH}_{2} \mathrm{CF}_{2}-$ at $1.1 \mathrm{ppm}$ and $\left(\mathrm{CH}_{3}\right)_{3} \mathrm{C}-$ $\mathrm{OCF}_{2} \mathrm{CH}_{2}-$ at $1.15 \mathrm{ppm}$. In addition, signals of small intensities are observed in the ${ }^{19} \mathrm{~F}$ NMR spectra at -60 and $-65 \mathrm{ppm}$. They are assigned to $\mathrm{CF}_{2}$ of $\left(\mathrm{CH}_{3}\right)_{3} \mathrm{C}-\mathrm{OCF}_{2} \mathrm{CH}_{2}-$ and confirm previous works dealing with the addition of tert- $\mathrm{BuO}^{\circ}$ onto the $\mathrm{CF}_{2}$ site of $\mathrm{VDF}^{43 d}$ or onto the $\mathrm{CF}_{2}$ site of PMVE $^{16 e}$. 
Both ${ }^{19} \mathrm{~F}$ and ${ }^{1} \mathrm{H}$ NMR spectra were used to assess the molecular weight of poly(VDF-co-CF $\left.5 \mathrm{MIII}\right)$ copolymers:

$$
\mathrm{N}_{\mathrm{VDF}}=\left[\left(\mathrm{I}_{2.3-2.5}+\mathrm{I}_{2.8-3.2}\right) / 2\right] /\left[\left(\mathrm{I}_{1.2}+\mathrm{I}_{1.8}\right) / 6\right]
$$

where $\mathrm{N}_{\mathrm{VDF}}$ is number of VDF units in copolymer and $\mathrm{I}_{i}$ are the integrals of $\mathrm{H}$ signals at given ppm, assuming recombination of macroradicals as a main termination reaction ${ }^{1 \mathrm{~d}}$.

${ }^{19} \mathrm{~F}$ NMR spectra yield the $\mathrm{SF}_{5} / \mathrm{VDF}$ molar ratio $\alpha$ in the copolymer. Hence, the molecular weights can be deduced from the following equation :

$$
\mathrm{Mn}=\mathrm{N}_{\mathrm{VDF}} \times 64+\alpha \mathrm{N}_{\mathrm{VDF}} \times 208+30
$$

Table 3 lists the molecular weights of binary poly(VDF-co-SF 5 MIII) copolymers obtained from equation (6).

In addition the solution polymerization used leads to lower molecular weights in contrast to polymerizations carried out in aqueous media (such as emulsion, miniemulsion or suspension) that result in higher molecular weights (as for poly(VDF-co-HFP) copolymers $)^{5}$.

Hence, because of the difficulty to introduce an $\mathrm{SF}_{5}$ comonomer into a copolymerization, we have found it worthwhile to carry out terpolymerizations of VDF, HFP and different $\mathrm{SF}_{5}$ containingmonomers - M-I, M-II, M-III, since it is known that the presence of HFP can enhance the reactivity of VDF and of the comonomer as recently reported in the case of $\mathrm{F}_{2} \mathrm{C}=\mathrm{CFO}-\mathrm{C}_{6} \mathrm{H}_{4}-\mathrm{Br}^{44}$. This is the case when one reactive couple of monomers can involve the third low- reactive monomer in terpolymerization.

$$
\mathrm{nH}_{2} \mathrm{C}=\mathrm{CF}_{2}+\mathrm{mF}_{2} \mathrm{C}=\mathrm{CFCF}_{3}+\mathrm{pXCY}=\mathrm{CZSF}_{5} \stackrel{\text { radical }}{\longrightarrow} \underset{\left(\mathrm{CH}_{2} \mathrm{CF}_{2}\right)_{\mathrm{t}}-\left(\mathrm{CF}_{2} \mathrm{CF}\right)_{\mathrm{u}}-(\mathrm{CXYCZ})_{\mathrm{v}} \underset{\mid}{\mid} \underset{\mathrm{q}}{\mathrm{CF}_{3}}}{\mathrm{SF}}
$$

Fig. 3: Radical terpolymerization of $\mathrm{SF}_{5}$ monomers with VDF and HFP.

\section{(II-2) Radical terpolymerization of SF 5 -containing monomers with VDF and HFP}

The expected terpolymers should contain an increased amount of fluorine in the polymer backbone (compared to the usual level of incorporation of HFP), which should improve the physicochemical properties of the resulting fluoropolymers.

A series of terpolymerizations were performed using an initial [initiator $]_{0} /[\text { total monomers }]_{0}$ molar ratio of $1 \%$. These radical-initiated polymerizations were carried out in a high pressure 11 
autoclave at $143{ }^{\circ} \mathrm{C}$ for $5 \mathrm{hrs}$ using di(tert-butyl)peroxide as the radical initiator and $1,1,1,3,3$ pentafluorobutane as the solvent (Figure 3). Upon completion of the reaction, the solvent was evaporated and, after precipitation and drying, the products were characterized by their ${ }^{1} \mathrm{H}$ and ${ }^{19} \mathrm{~F}$ NMR spectra, which allowed characterization of the microstructures of these terpolymers. Depending on the identity of the $\mathrm{SF}_{5}$-containing monomer and of the initial molar ratios, three different types of terpolymers were obtained: (a) a brown high viscous liquid oligomer (I) when using the $\mathrm{SF}_{5}$ monomer M-I, which bears three $\mathrm{H}$ atoms on the vinyl group; (b) a brown rubber-like polymer (II) when using $\mathrm{SF}_{5}$ monomer (M-II); and (c) a grey rubber-like polymer (III) when using the perfluorinated monomer M-III. Regarding solubilities of the polymers, all of them were soluble in acetone, THF and in 1,1,1,3,3-pentafluorobutane, whereas terpolymer III, based on the perfluorinated $\mathrm{SF}_{5}$ monomer was also soluble in dichloromethane and partially in chloroform. It was also noted that the higher the fluorine content of the $\mathrm{SF}_{5}$ comonomer, the higher the yield of the reaction, and the higher the initiator concentration, the greater the yield (Table 4).

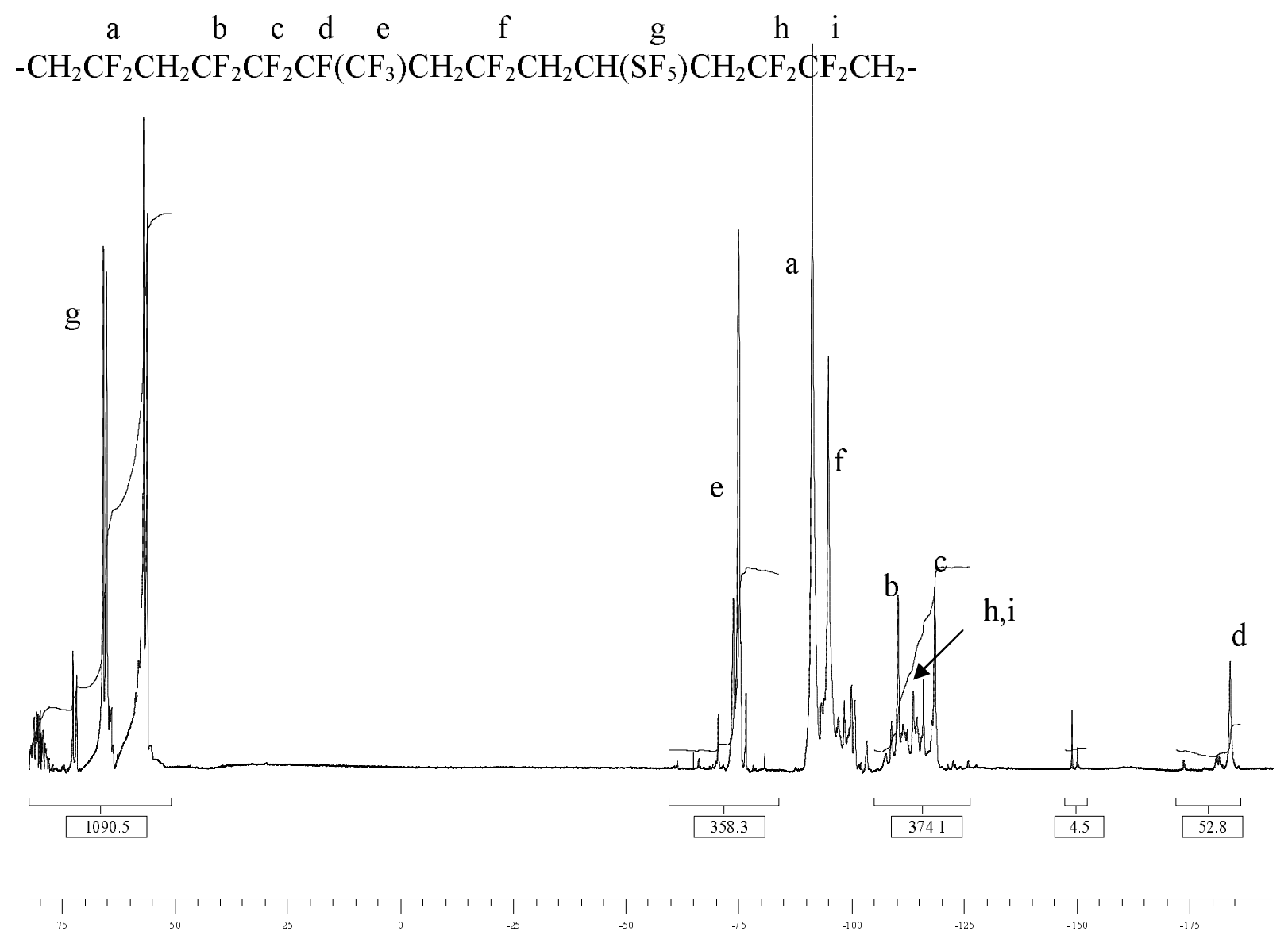

Fig. $4{ }^{19} \mathrm{~F}$ NMR spectrum of poly(VDFter-HFP-ter-SF $5(\mathrm{M}-\mathrm{I})$ ) terpolymer I at initial monomer ratio in the feed $=72.0 / 19.4 / 8.6 \mathrm{~mol} \%$ 
a

$-\mathrm{CH}_{2} \mathrm{CF}_{2} \mathrm{CH}_{2} \mathrm{CF}_{2} \mathrm{CF}_{2} \mathrm{CF}\left(\mathrm{CF}_{3}\right) \mathrm{CH}_{2} \mathrm{CF}_{2} \mathrm{CH}_{2} \mathrm{CH}\left(\mathrm{SF}_{5}\right) \mathrm{CF}_{2} \mathrm{CH}_{2} \mathrm{CH}_{2} \mathrm{CF}_{2-}$

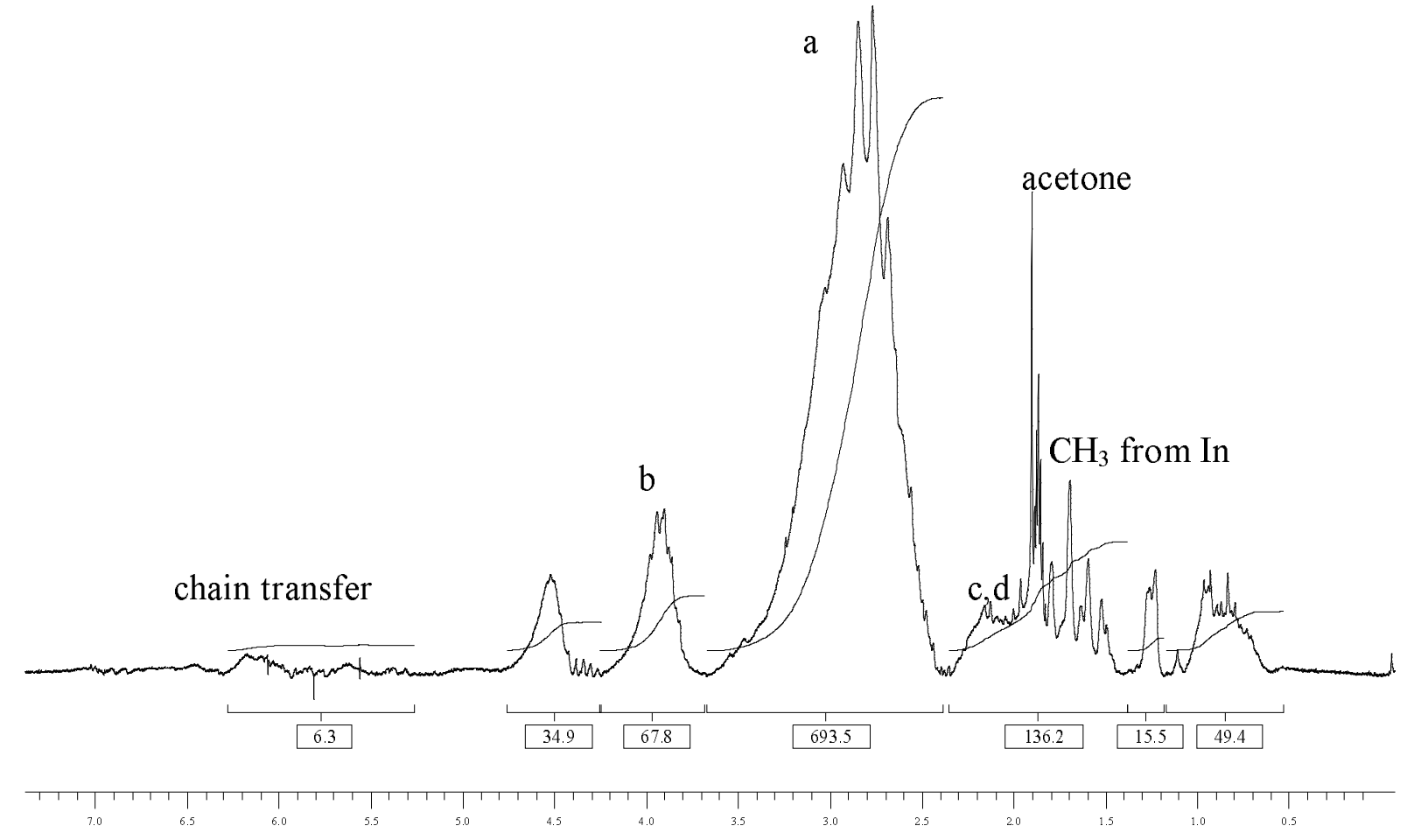

Fig $.5{ }^{1} \mathrm{H}$ NMR spectrum of poly(VDFter-HFP-ter-SF $5(\mathrm{M}-\mathrm{I})$ ) terpolymer I at initial monomer ratio in the feed $=72.0 / 19.4 / 8.6 \mathrm{~mol} \%$

On the basis of such analyses, it was concluded that in all cases statistical terpolymers were obtained wherein the different monomeric units were randomly distributed in the backbone, and where microblocks of oligo(VDF)s could be noted in the terpolymer. The relative amounts of the monomers in the terpolymers were assessed by ${ }^{19} \mathrm{~F}$ NMR spectroscopy (Figures 4 and 6). In addition, all ${ }^{1} \mathrm{H}$ NMR spectra( Figures 5 and 7) exhibit signals that can be assigned to the methylene groups of VDF units adjacent to difluoromethylene groups in the $2.5-3.5 \mathrm{ppm}$ range (with the high amounts of VDF units in the terpolymer, small amounts of head-to-head addition can also be seen, which gives rise to signals at about $2.2-2.4 \mathrm{ppm}$ ). The low intensity of the signals and absence of any triplet of triplets and of doublet of multiplets centered at 6.3 and $5.6 \mathrm{ppm}$, assigned to $-\mathrm{CH}_{2} \mathrm{CF}_{2} \mathrm{H}$ and $\mathrm{CF}_{2} \mathrm{CFHCF}_{3}$, respectively, gave evidence that very little (Figure 5) or no (Figure 7) chain transfer reaction occurred. 
$\begin{array}{llllllllllllllll}\text { a } & b & \text { c } & d & \text { e } & f & g & h & k & 1 & m\end{array}$

$-\mathrm{CH}_{2} \mathrm{CF}_{2} \mathrm{CH}_{2} \mathrm{CF}_{2} \mathrm{CF}_{2} \mathrm{CF}\left(\mathrm{CF}_{3}\right) \mathrm{CH}_{2} \mathrm{CF}_{2} \mathrm{CF}_{2} \mathrm{CF}\left(\mathrm{SF}_{5}\right) \mathrm{CH}_{2} \mathrm{CF}_{2} \mathrm{CF}_{2} \mathrm{CH}_{2}-$

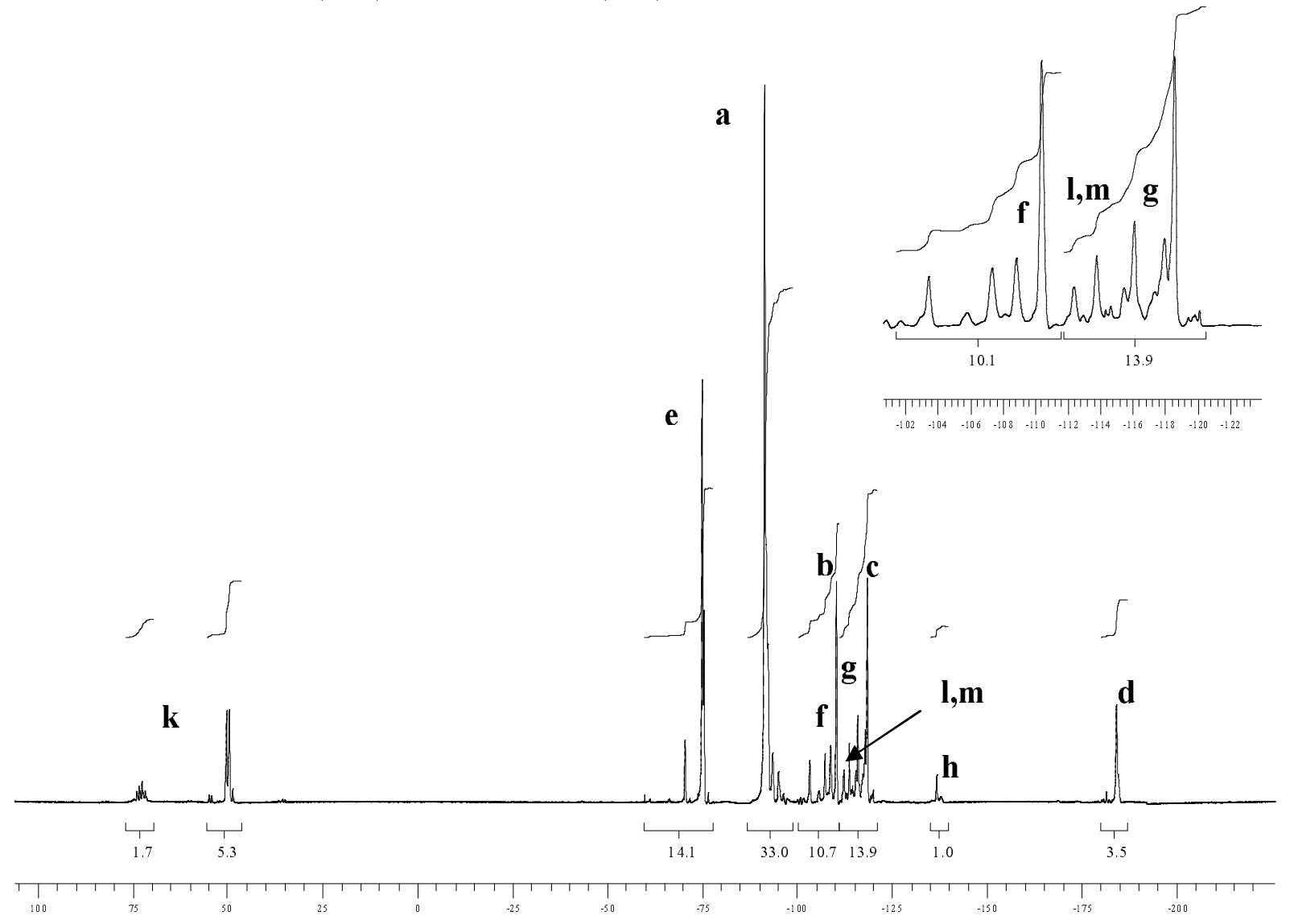

Fig. $6{ }^{19} \mathrm{~F}$ NMR spectrum of poly(VDFter-HFP-ter-SF 5 (M-III)) terpolymer III recorded in deuterated acetone at initial monomer ratio $73.1 / 18.3 / 8.6 \mathrm{~mol} \%$

II-2-1) Determination of the terpolymer compositions by using ${ }^{19} \mathrm{~F}$ NMR spectra

Radical terpolymerizations in solution with organic initiators of $\mathrm{SF}_{5}$-containing monomers such as M-I, M-II and M-III, have not been previously reported in the literature. The main goal of this part was thus to identify those peaks characteristic of such comonomers in the terpolymers. In contrast, the determination of the various NMR signals deriving from VDF and HFP units in co- and terpolymers has been the subject of various papers ${ }^{7,16 e, 41,44,46}$. 
The ${ }^{19}$ F NMR spectra of polymers I and III (Fig. 4,6) as well as polymer II exhibit the characteristic signals centered at $-91,-94,-107,-110,-113.7$ and $-116 \mathrm{ppm}$ assigned to the difluoromethylene groups of VDF in the normal addition, adjacent to a $\mathrm{F}_{2} \mathrm{C}=\mathrm{CFSF}_{5}$ unit, and to reverse addition : $-\mathrm{CH}_{2} \underline{\mathbf{C F}}_{2}{ }^{-}$ $\mathrm{CF}_{2} \mathrm{CH}_{2}-\mathrm{CH}_{2} \mathrm{CF}_{2-}$ and $-\mathrm{CH}_{2} \mathrm{CF}_{2} \underline{\mathrm{CF}}_{2} \mathrm{CH}_{2}-\mathrm{CH}_{2} \mathrm{CF}_{2-}{ }^{43}$, respectively as observed in NMR spectra of copolymers (Table 2). The signals located at -108 ppm (noted $\mathrm{I}_{-108}$ ) and -110.1 (noted $\mathrm{I}_{-110.1}$ ) range are

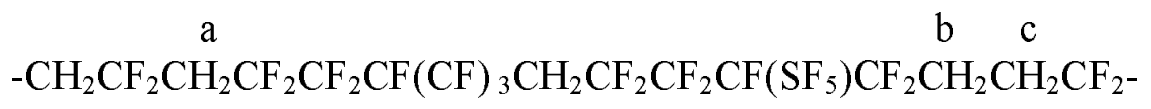

GB4H-Aceto

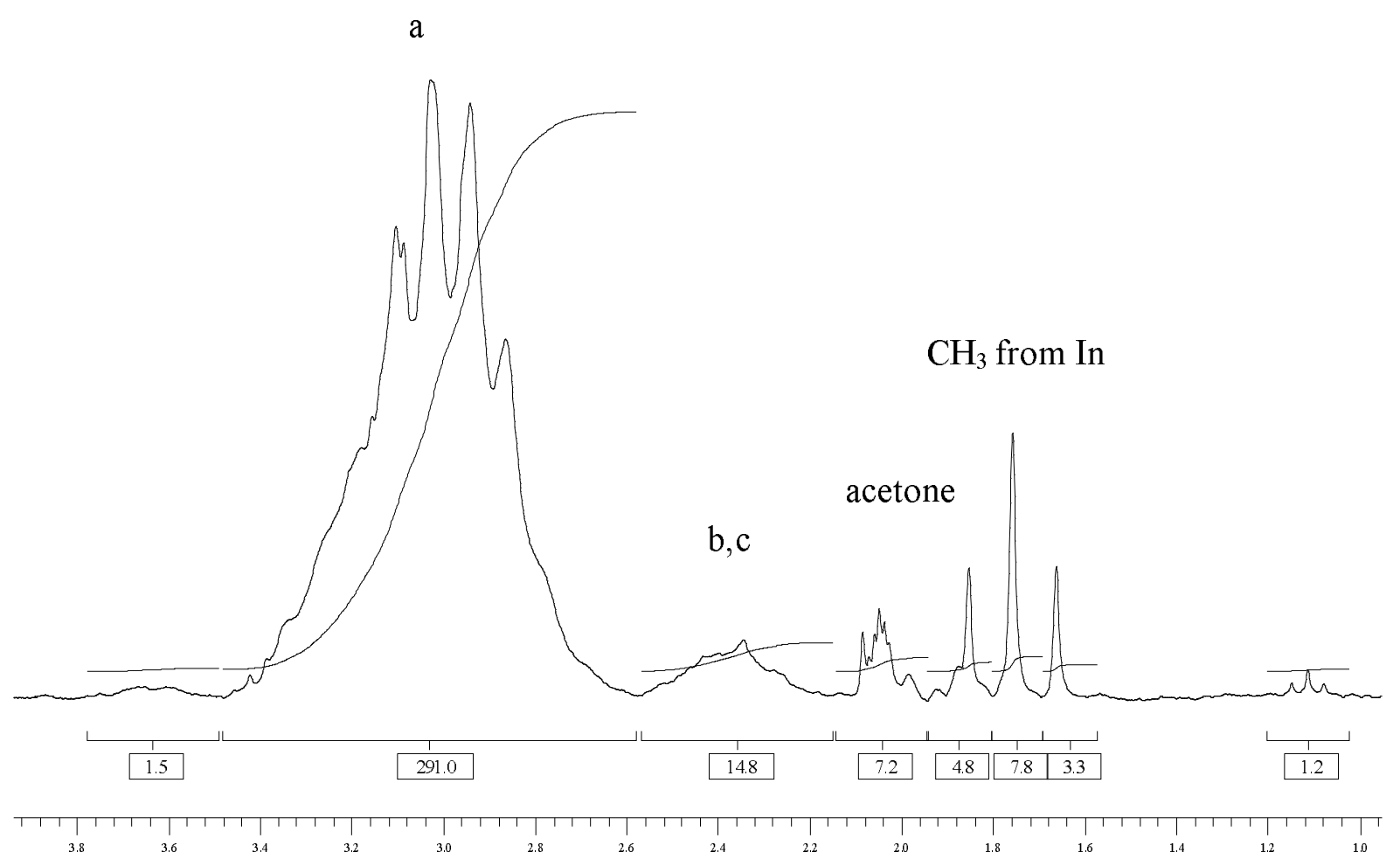

Fig. $7{ }^{1} \mathrm{H}$ NMR spectrum of poly(VDFter-HFP-ter-SF 5 (M-III)) terpolymer III recorded in deuterated acetone at initial monomer ratio 73.1/18.3/8.6 mol \%

assigned to the difluoromethylene groups of the VDF unit adjacent to HFP and $\mathrm{SF}_{5} \mathrm{M}$ unit, respectively.

In addition, the chemical shifts centered at -71.2 (noted $\mathrm{I}_{-71.2}$ ), -74.8 (noted $\mathrm{I}_{-74.8}$ ) are assigned to the trifluoromethyl side group of HFP in the terpolymer: $-\mathrm{CH}_{2} \mathrm{CF}_{2} \mathrm{CF}_{2} \mathrm{CF}\left(\mathrm{CF}_{3}\right)-\mathrm{CF}_{2}-\mathrm{CH}_{2^{-}},-\mathrm{CH}_{2}-\mathrm{CF}_{2^{-}}$ $\mathrm{CF}_{2}-\mathrm{CF}\left(\mathrm{CF}_{3}\right)-\mathrm{CH}_{2}-\mathrm{CF}_{2-}$, while those centered at -118.8 (noted $\mathrm{I}_{-118.8}$ ) and -183.5 (noted $\mathrm{I}_{-183.5}$ ) ppm are attributed to the HFP difluoromethylene groups in $-\mathrm{CH}_{2} \mathrm{CF}_{2} \mathrm{CF}_{2} \mathrm{CF}\left(\mathrm{CF}_{3}\right)-$ sequences and to the tertiary fluorine in $\mathrm{CF}_{2} \mathrm{CF}\left(\mathrm{CF}_{3}\right)$ of $\mathrm{HFP}^{41}$, respectively. 
Finally, the multiplets centered at $-114.0 \mathrm{ppm}$ (noted $\mathrm{I}_{-114.0}$ ) and - $112.0 \mathrm{ppm}$ (noted $\mathrm{I}_{-112.0}$ ) are attributed to the difluoromethylenes of the $\mathrm{SF}_{5} \mathrm{M}$ unit in terpolymers III and II: $-\left(\mathrm{CF}_{2}-\mathrm{CF}\left(\mathrm{SF}_{5}\right)\right)$ - and $\mathrm{CF}_{2}-\mathrm{CH}\left(\mathrm{SF}_{5}\right)$ )), respectively. Also, the peaks located in the $-137.6 \mathrm{ppm}$ region (noted $\mathrm{I}_{-137}$ ) are assigned to the tertiary fluorine atom in the CF group of $-\left(\mathrm{CF}_{2}-\mathrm{CF}\left(\mathrm{SF}_{5}\right)\right)-$ monomer unit in polymer III. The multiplets centered at +55 and $+75 \mathrm{ppm}$ in the ${ }^{19} \mathrm{~F}$ NMR are consistent with the presence the $\mathrm{SF}_{5}$ group. The $\mathrm{SF}_{5}$ group, as found by Muller et al. ${ }^{47}$, contains four magnetically equivalent and one non equivalent fluorine atoms $\left(\mathrm{AB}_{4}\right.$ system). The equatorial, $\mathrm{A}_{4}$, resonance is split into a doublet while the apex, A, resonance is grossly a pentet with a 'fine structure'. Cross et al. ${ }^{48}$ reported that the compounds in which the $\mathrm{SF}_{5}$ group is bound to aliphatic hydrocarbons, a very intense broad band centered on or about $870 \mathrm{~cm}^{-1}$ is found. They assigned this to the S-F stretching modes. We observed the same behavior with our compounds.

The integrals in the ${ }^{19} \mathrm{~F}$ NMR spectra (denoted above), allow the determination of the molar fractions of VDF, HFP and $\mathrm{SF}_{5} \mathrm{M}$ units in the terpolymers, and they are given by the following equations (Eq. 7):

$$
\begin{aligned}
& \text { Mol \% of VDF in the terpolymer }=\frac{I_{J}}{I_{J}+I_{K}+I_{L}} \times 100 \\
& \text { Mol \% of HFP in the terpolymer }=\frac{I_{K}}{I_{J}+I_{K}+I_{L}} \times 100 \\
& \text { Mol \% of SF } 5 \text { in the terpolymer }=\frac{I_{L}}{I_{J}+I_{K}+I_{L}} \times 100
\end{aligned}
$$

where,

$$
\begin{aligned}
\mathrm{I}_{\mathrm{J}} & =\frac{\mathrm{I}_{-91.1}+\mathrm{I}_{-94.9}+\mathrm{I}_{-109.8}+\mathrm{I}_{-110.1}+2 \times \mathrm{I}_{-1157}}{2} \\
\mathrm{I}_{\mathrm{K}} & =\frac{\mathrm{I}_{-71.2}+\mathrm{I}_{-74.8}}{3} \text { or } \quad \mathrm{I}_{\mathrm{K}}=\mathrm{I}_{-119} / 2 \\
\mathrm{I}_{\mathrm{L}} & =\mathrm{I}_{+50 \text { to }+75} / 5 \text { or } \mathrm{I}_{\mathrm{L}}=\mathrm{I}_{-135}
\end{aligned}
$$

The degrees of incorporation of each monomer in the terpolymers are listed in Table 4.

\section{III-5) Characterization of the terpolymers}

Table 4 lists the final molar percentages of each termonomer and also the physico-chemical properties of each terpolymer. 
In the same experimental conditions (experiments I, II and III: terpolymer VDF / HFP / $\mathrm{SF}_{5} \mathrm{M}$, starting from the same $\mathrm{SF}_{5} \mathrm{M}$ feed molar percentages of ca. $8.6 \mathrm{~mol} \%$ led to copolymers containing 17.4, 2.1, and $5.3 \mathrm{~mol} . \%$, respectively (Table 4). The increasing mol. $\%$ of $\mathrm{SF}_{5} \mathrm{M}$ in feed makes increasing its mol. \% in the terpolymer and the yield. Usually, the final molar percentages of VDF is higher than the molar percentages in feed. As a matter of fact, this result is the evidence of the presence of oligo(VDF) blocks separated by one $\mathrm{SF}_{5}$ monomeric unit in the terpolymer. The poor reactivity of $\mathrm{F}_{2} \mathrm{C}=\mathrm{CH}\left(\mathrm{SF}_{5}\right)$ monomer is not surprising when its behavior is compared to that of $\mathrm{F}_{2} \mathrm{C}=\mathrm{CH}\left(\mathrm{CF}_{3}\right)^{49}$ or $\mathrm{F}_{2} \mathrm{C}=\mathrm{CH}\left(\mathrm{C}_{6} \mathrm{~F}_{13}\right), 1 \mathrm{HPFO}^{50}$. Actually, kinetics of copolymerization of both of these fluorinated monomers led to the following reactivity ratios :

$$
\begin{array}{lll}
\mathrm{r}_{\mathrm{PFP}}=0.06 ; & \mathrm{r}_{\mathrm{VDF}}=9.0 & \text { at } 40^{\circ} \mathrm{C} \\
\mathrm{r}_{1 \mathrm{HFPO}}=0.9 ; & \mathrm{r}_{\mathrm{VDF}}=12.0 & \text { at } 75^{\circ} \mathrm{C}
\end{array}
$$

These values show the low reactivity of the above mentioned fluorinated alkenes vs. VDF.

While the ${ }^{19} \mathrm{~F}$ NMR spectroscopy shows the insertion of VDF and HFP base units in the terpolymers, several methods were used to characterize these fluorinated terpolymers: the molecular weights by size exclusion chromatography (SEC with PMMA standards, the polymers were soluble in THF) and the thermal properties by differential scanning calorimetry (DSC) and thermogravimetric analyses (TGA).

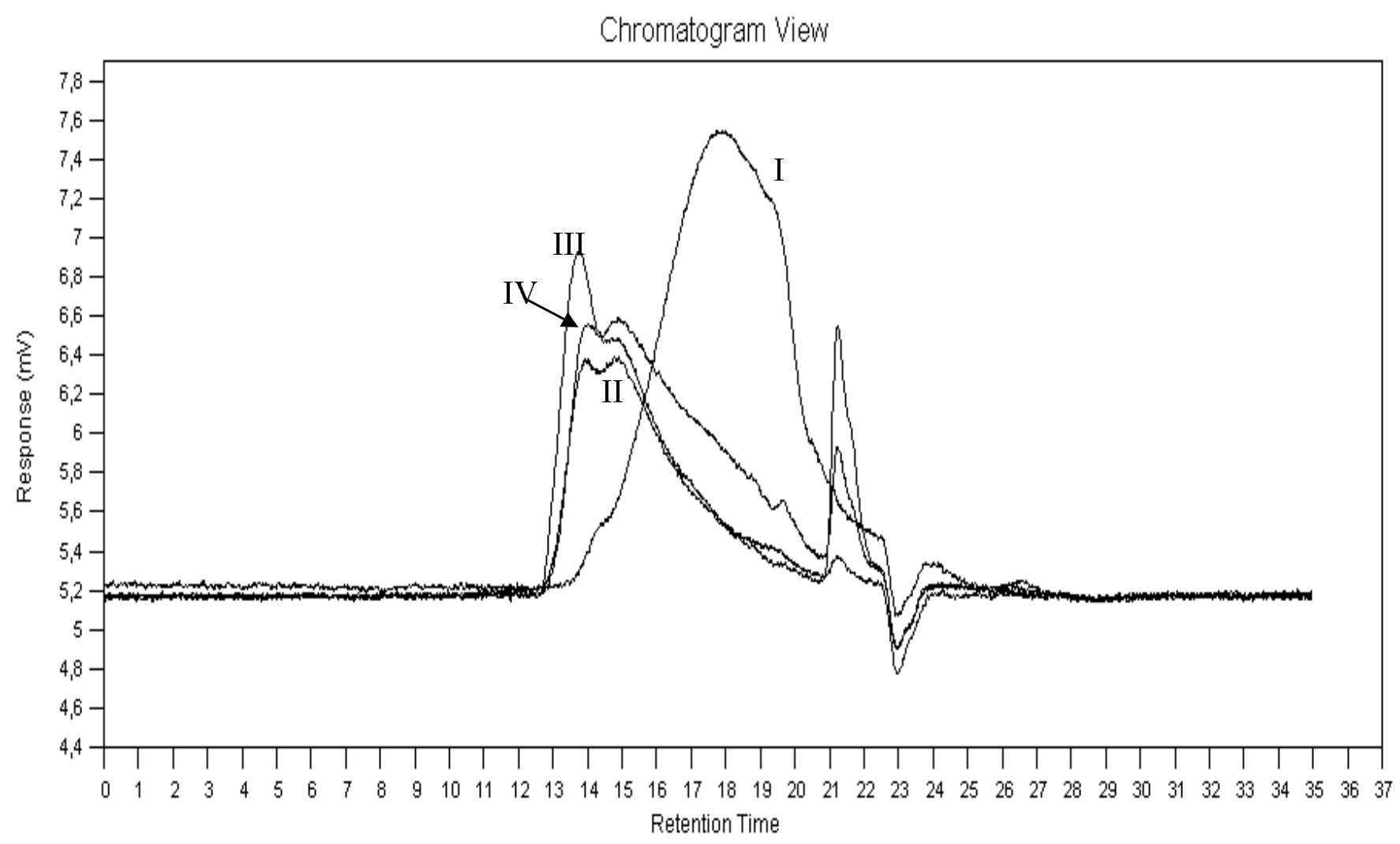


Fig. 8 SEC Chromatograms of poly(VDF-ter-HFP-ter-SF 5 M) terpolymers. Terpolymer compositions of $\mathrm{VDF} / \mathrm{HFP} / \mathrm{SF}_{5} \mathrm{M}$ in mol \% :I -71.0/11.6/17.4 ;II- 83.8/14.1/2.1; III - 78.3/16.4/5.3; IV $78.1 / 13.5 / 8.3$

In all cases, the SEC chromatograms (Figure 8) showed one main maximum with two shoulders. This can be surprising for terpolymers for which monomodal distribution is expected, although more detailed experiments required to be done. The value of the average molecular weights, $\overline{\mathbf{M n}_{\mathbf{n}}}$, of poly(VDF-ter-HFP-ter-SF 5 M) terpolymers (experiments I, II and III with ca. $8.6 \mathrm{~mol} \%$ in feed of fluorinated $\mathrm{SF}_{5}$ monomer) or poly(VDF-ter-HFP-ter-SF 5 M) terpolymers (experiment IV), $13.6 \mathrm{~mol} \%$ in feed of perfluorinated $\mathrm{SF}_{5}$ monomer) were about 2540, 8290,10030, and $6650 \mathrm{~g} \cdot \mathrm{mol}^{-1}$, respectively (Table 4). The SEC chromatograms shown in Figure 8 also indicate some low molecular weightproducts tailing in the range of monomers. The maximum of the SEC traces shifted towards higher molecular weight with increasing of fluorine atom in $\mathrm{SF}_{5} \mathrm{M}$ for the main part of the copolymer obtained. In the case of experiments III and IV, the lower molecular weight in the latter is, as expected, due to the higher concentration of DTBP initiator ( $3 \mathrm{~mol} \%$ vs. $1 \mathrm{~mol} \%$ ). However, these measurements cannot be considered quite accurate because of the lack of standards for VDF polymers. The polydispersity index of terpolymers synthesized is in the range of the statistic distribution (2.02.4).

The transfer reaction on the macroradical appears to be quite negligible on the basis of the small presence of transfer signals in ${ }^{19} \mathrm{~F}$ and ${ }^{1} \mathrm{H}$ NMR spectra (few presence of triplet of triplets and doublet of multiplets centered at 6.1 and $5.5 \mathrm{ppm}$ assigned to $-\mathrm{CH}_{2} \mathrm{CF}_{2} \mathrm{H}$ and $-\mathrm{CF}_{2} \mathrm{CF}\left(\mathrm{CF}_{3}\right) \mathrm{H}$, respectively. On the other hand using the same strategy of binary poly(VDF-co-SF 5 MIII) copolymers, the molecular weights of terpolymers can be assessed by ${ }^{1} \mathrm{H}$ and ${ }^{19} \mathrm{~F}$ NMR analyses. The equation 6 can be modified as follows :

$$
\mathrm{Mn}=\mathrm{N}_{\mathrm{VDF}} \times 64+\alpha_{1} \mathrm{~N}_{\mathrm{VDF}} \times 150+\alpha_{2} \mathrm{~N}_{\mathrm{VDF}} \times \mathrm{MsF}_{5} \mathrm{M}_{\mathrm{i}}+30
$$

where $\alpha_{1}$ and $\alpha_{2}$ are the molar ratios of HFP and $\mathrm{SF}_{5} \mathrm{M}_{\mathrm{i}}$ monomer units vs. VDF and $\mathrm{MsF}_{5} \mathrm{M}_{\mathrm{i}}$ are the molecular weights of $\mathrm{SF}_{5} \mathrm{MI}, \mathrm{SF}_{5} \mathrm{MII}$ and $\mathrm{SF}_{5} \mathrm{MIII}$ monomers, respectively. The results obtained are shown in Table 3 and compared to SEC molecular weights. They follow the same tendency, but they have higher values than SEC ones as was discussed before.

Thermogravimetry curves (Figure 9) show that these terpolymers exhibit a good thermal stability since their decomposition started from 170 to $250^{\circ} \mathrm{C}$, for poly(VDF-ter-HFP-ter- $\mathrm{SF}_{5}$ ) terpolymers. For example, terpolymer I (curve I) is the least thermal stable because of the entirely hydrogenated vinyl group in M-I. The higher the fluorine content the higher thermostability of the obtained terpolymer. The glass transition temperatures ( $\mathrm{Tg}$ ) of the different fluorinated terpolymers were assessed by differential scanning calorimetry (DSC) and the results are listed in Table 3 . In the poly(VDF-ter-HFP18 
ter-SF5M) terpolymers, Tgs were ranging from -40 to $-50{ }^{\circ} \mathrm{C}$ without any other transitions, showing amorphous behavior. With such $\mathrm{T}_{\mathrm{g}} \mathrm{S}$, and as reported in the literature ${ }^{8,9}$, it is known that fluoropolymers containing VDF and HFP base units only, exhibit average $\mathrm{T}_{\mathrm{g}}$ of $-26^{\circ} \mathrm{C}$ and are fluoroelastomers.

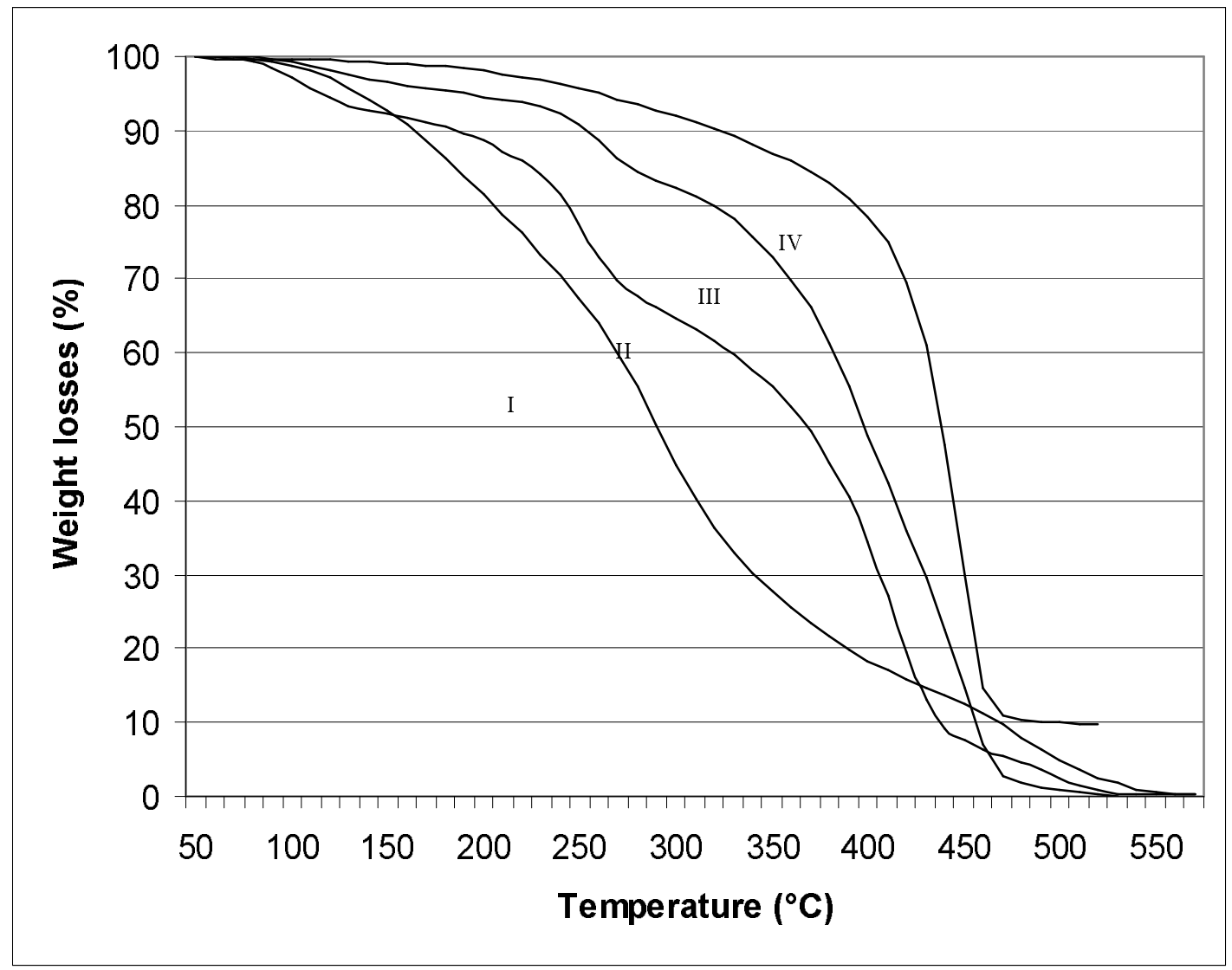

Fig.9 Thermogravimetric curves of poly(VDFter-HFP-ter-SF 5 M) terpolymers in air of $\mathrm{VDF} / \mathrm{HFP} / \mathrm{SF}_{5}$ terpolymers. Terpolymer compositions of VDF/HFP/SF $5 \mathrm{M}$ in $\mathrm{mol} \%$ :I -71.0/11.6/17.4 ;II-

$$
\text { 83.8/14.1/2.1; III - 78.3/16.4/5.3; IV - 78.1/13.5/8.3 }
$$

Finally, regarding the results gathered in Table 4, it appears that the hydrogenated monomer M-I is more reactive than $\mathrm{M}-\mathrm{II}$ and $\mathrm{M}$-III monomers containing two and three F-atoms in the vinyl group, respectively. 


\section{CONCLUSION}

Monomers $\mathrm{CH}_{2}=\mathrm{CHSF}_{5}, \mathrm{M}-\mathrm{I}$ and $\mathrm{CF}_{2}=\mathrm{CHSF}_{5}, \mathrm{M}-\mathrm{II}$ were prepared by using a new Et $\mathrm{B}_{3}$-initiation methodology to add $\mathrm{SF}_{5} \mathrm{Cl}$ to ethylene and $\mathrm{VDF}$, respectively. $\mathrm{CF}_{2}=\mathrm{CFSF}_{5}$, M-III monomer was synthesized by radical addition of $\mathrm{BrSF}_{5}$ onto trifluoroethylene followed by a dehydrobromination. It was found that M-III monomer does not homopolymerize but copolymerizes with VDF by free radical initiation. Its reactivity with VDF when compared to that of other fluoroalkenes (HFP, PMVE and PPVE) gives the following decreasing series:

\section{HFP $>$ PPVE $>$ PMVE $>\mathrm{SF}_{5} \mathrm{M}$}

i.e. the M-III monomer has the lowest reactivity due to the $\mathrm{SF}_{5}$ bulky-side groups.

The terpolymerization of $\mathrm{SF}_{5}$ containing monomers with vinylidene fluoride (VDF), hexafluoropropene (HFP) in organic solvent and peroxyde initiator has been described for the first time. Indeed, it has been shown that radical polymerization of $\mathrm{SF}_{5} \mathrm{M}$ can be successfully performed in 1,1,1,3,3-pentafluorobutane initiated by di(tert-butylperoxide). Interestingly, the terpolymerization of VDF with HFP and $\mathrm{SF}_{5} \mathrm{M}$ shows that $\mathrm{CH}_{2}=\mathrm{CHSF}_{5}$ monomer was more reactive than $\mathrm{CF}_{2}=\mathrm{CHSF}_{5}$ and even more reactive than $\mathrm{CF}_{2}=\mathrm{CFSF}_{5}$.

$$
\mathrm{CH}_{2}=\mathrm{CH}\left(\mathrm{SF}_{5}\right)>\mathrm{F}_{2} \mathrm{C}=\mathrm{CF}\left(\mathrm{SF}_{5}\right)>\mathrm{F}_{2} \mathrm{C}=\mathrm{CH}\left(\mathrm{SF}_{5}\right)
$$

Both ${ }^{1} \mathrm{H}$ and ${ }^{19} \mathrm{~F}$ NMR analyses enabled the calculation of molecular weight of binary and ternary $\mathrm{SF}_{5} \mathrm{M}$ copolymers.

Finally, DSC, TGA and GPC analyses indicated that the terpolymers II and III incorporating $\mathrm{SF}_{5}$ side groups exhibited better thermal properties and higher molecular weights than terpolymer I. Further work on these materials, including combustion tests, is in progress.

\section{$\underline{\text { Acknowledgments }}$}

The authors thank the Solvay S.A. (Tavaux and Brussels in France and Belgium, respectively) for the generous gifts of vinylidene fluoride, hexafluoropropene, and 1,1,1,3,3-pentafluorobutane.

\section{SUPPORTING INFORMATION}

NMR and FT-IR spectra, and DSC curves can be found free of charge on http//acs.org. 


\section{REFERENCES}

(1) a) Feiring, A.E. «Fluoroplastics » In: Banks R.E., Smart B.E., Tatlow J.C. Ed., Organofluorine Chemistry: Principles and Commercial Applications, New York Plenum Press 1994, 15, 339-372; b)

Scheirs, J.; Modern Fluoropolymers, Wiley, New York, 1997; c) Hougham, G.; Davidson, T.; Cassidy, P.; Johns, K. Fluoropolymers, Kluvert, New-York, 1999; d) Ameduri, B.; Boutevin, B. WellArchitectured Fluoropolymers: Synthesis, Properties and Applications, Elsevier, Amsterdam, 2004.

(2) Banks, B.A. The use of Fluoropolymers in Space Applications, Modern Fluoropolymers, (J. Scheirs, Ed.) Wiley and Sons, 1999, Chapter 4, 103-114.

(3) a) Kobayashi, T.; Munekuta, S.; Unoki, E. European Patent 239,935, 1987 ; b)Yamamoto, S.; Matsumoto, M.; Shimada, T. European Patent 256,765, 1988; c) Skutnik, K. AU Patent 569,145, 1988.

(4) Boutevin, B.; Pietrasanta, Y. "Les Acrylates et poly Acrylates fluorés", Erec, Paris, 1998.

(5) Brady, R.. Chem. in Britain, 1990, 26(5), 427-438.

(6) a) Tournut, C. Macromol. Symp. 1994, 82, 99-109; b) Tournut, C. J. « Thermoplastic Copolymers of Vinylidene Fluoride » In: Scheirs J., Ed Modern Fluoropolymers, Wiley, New York, 1997 in Ref. 1b), Chap. 31, pp. 577-596.

(7) a) Cook, D.; Lynn, M. Rapra Review Reports 1995, 3, Report 32, Shrewbury, pp. 1-27;

b) Logothetis A. L. Prog. Polym. Sc. 1989, 14, 251-285; c) Van Cleef, A. « Fluoroelastomers» in: Scheirs J. Ed. Modern Fluoropolymers, Wiley, New York, 1997, in Ref. 1b), Chap. 32, pp. 597-614; d) Ameduri,B.; Boutevin, B.; Kostov, G. Prog. Polym. Sc. 2001, 26, 105-187.

(8) a) Arcella, V.; Brinati, G.; Albano, M.; Tortelli, V. (Ausimont S.p.A.). Eur. Pat. Appl. 0661312A1, July 5, 1995 ; b)Arcella, V.; Brinati, G.; Albano, M.; Tortelli, V. (Ausimont S.p.A.). Eur. Pat. Appl. 0683186A1, November 22, 1995; c) Hull, D. E.; Johnson, B.V.; Rodricks, J.P.; Staley, J.B. Modern, «THV Fluoroplastic », in: Scheirs J., Ed., Fluoropolymers, Wiley, New York, 1997, in Ref. 1b), Chapter 13, pp. 257-270; d) Gayer, U.; Schuh, T.; Arcella, V.; Albano, M. (Ausimont S.p.A). Eur. Pat. App1. EP1231239A1, August 8, 2002

(9) a) Arcella, V.; Ferro, R. «Fluorocarbon Elastomers », in Scheirs J., Ed., Modern Fluoropolymers, Wiley, New York, 1997 in ref. 1b), chapter 2, pp 71-98; b) Kostov, G.; Ameduri, B.; Bauduin, G.; Boutevin, B.; Stankova, M. J. Polym. Sci. Part A: Polym. Chem. 2004, 42, 1693-1706.

(10) a) Minhas, P.S.; Petrucelli, F. Plast. Eng. 1977, 33, 60-71; b) CMX ${ }^{\circledR}$ Technical Brochure, Allied, 1992.

(11) Souzy, R.; Guiot, J.; Ameduri, B.; Boutevin, B.; Paleta, O. Macromolecules 2003, 36(25), 93909395.

(12) Souzy, R.; Ameduri, B.; Boutevin B., Macromol. Chem. Phys. 2004, 205, 476-485. 
(13) a) Ohmori, A.; Tomihashi, N.; Inukai, H.; Shimizu, Y. (Daikin Kogyo Co). Eur. Pat.Appl. 0,138,091, August 20, 1984; b) Ameduri, B.; Boutevin, B.; Kostov, G.; Petrova, P. J. Fluorine Chem. 1999, 93, 139-145; c) Guiot, J.; Ameduri, B.; Boutevin, B. J. Polym. Sci., Part A: Polym. Chem. 2002, $40,3534-3643$.

(14) Ameduri, B.; Bauduin, G.; Boutevin, B.; Kostov, G.; Petrova, P. Macromolecules 1999, 32, 45444550 .

(15) a) Ameduri, B.; Boutevin, B.; Kostov, G.; Petrova, P. Designed Monomers Polym. 1999, 2, $267-$ 285; b) Petrova, P.; Ameduri, B.; Boutevin, B.; Kostov, G. (Solvay Solexis). US Patent 20046753392; June 22, 2004.

(16) a) Connolly, D.J.; Gresham, W.F. US Patent 3,282,875, November 1, 1966 (Du Pont); b) Feiring, A.E.; Doyle, C.M.; Roelofs, M.G.; Farnham, W.B.; Bekiaran, P.G.; Blair, H.A.K. (Du Pont). PCT WO 99/45048, 1999; c) Farnham, W.B.; Feiring, A.E.; Morken, P. (Du Pont). WO 99/41292A, August 19, 1999; d) Farnham, W.B.;Bekarian, P.G.(Du Pont).WO 00/52060A,September 8, 2000; e)Bekiaran P.G., Doyele, C.M.; Farnham, W.B.; Feiring, A.E.; Morken, M.G. J.Fluorine Chem.2004,125,11871204;e) Ameduri,B.;Armand,M.; Boucher,M.;Manseri,A.(Hydro-Quebec).WO 01/49757,July 12,2001. (17) a)Worm, A. (Dyneon). PCT WO 00/12574, March 9, 2001; b) Ameduri, B.; Boucher, M.; Manseri, A. (Hydro-Quebec) PCT CA 01/01439, October 12, 2001.

(18) a) Apotheker, D.; Krusic, P.J. (Du Pont). USP 4,214,060, November 30, 1976; b) Moggi, G.; Bonardelli, P.; Monti, C.; Bart, J.C.J. Polym. Bull. 1984, 11, 35-40 ; c) Chiodino, G.; Lagostina, A.; Merenda, M.; Minutillo, A.; Montessoro, E. (Ausimont). Eur. Pat. Appl., 0,410,351 B1, 1993; d) Ameduri, B.; Boucher, M.; Manseri, A. (Hydro-Quebec). WO 01/96268, December 20, 2001 ; e) Guiot, J.; Neouze, M.A.; Sauguet ,L.; Ameduri, B.; Boutevin, B. J. Polym. Sc. Part A Polym. Chem. 2005, 43, 917-932.

(19) a) Schuman, P. D.; Sci. Tech. Aerosp. Rep. 1968, 6, 957-988; b) Schmiegel, W. W. Angew. Makromol. Chem. 1979, 76/77, 39-57; c) Tatemoto, M.; Amano, T. (Daikin). Eur. Pat. Sp. 0,077,998, October 19, 1982 ; d) Yamabe, M.; Kojima, M.; Wachi, G. H.; Kodama, S. (Asahi Glass Co Ltd). USP 4,418,186, November 29, 1983; e) Albano, M.; Arcella, V.; Chiodini, G.; Minutillo, A. (Ausimont). EP 0,618,241 B1, March 24, 1994; f) Kruger, R.; Piejko, K. E.; Negele, M.; Eisele, U.; Marhold, A. (Bayer). USP 5,426,165, June 20, 1995; h) Ameduri, B.; Boutevin, B.; Armand, M.; Boucher, M. (Hydro-Quebec). WO 01/49758, July 12, 2001.

(20) Terjeson, R.J.; Gard, G.L. J.Fluorine Chem., 1987, 35, 653-659.

(21) Gard, G.L.; Winter, R.; Nixon, P.G.; Hu, Y.-H.; Holcomb, N.R.; Grainger ,D.W.; Castner, D.G. Polymer Preprint, 1998, 39, 962-963.

(22) Yan, M.; Gard, G.L; Mohtasham, J.; Winter, R.W.; Lin „J.; Wamser, C.C. Polymer News, 2001, $26,283-288$. 
(23)Winter, R.W.; Dodean, R.A.; Gard,G.L."SF5 Synthons-Pathways to Organic Derivatives of SF6" In: ", Soloshonok, V.A. Ed; "Fluorine-Containing Synthons; ACS Publications Division and Oxford University Press, Washington, D.C., Chapt 4, pp 87-119 (2005).

(24) a) Winter, R.; Nixon, P.G.; Gard ,G.L.; Castner, D.G.; Holcomb, N.R.; Hu, Y.-H.; Grainger, D.W. Chem. Mater., 1999, 11, 3044-3049; b) Winter R., Nixon P.G., Terjeson R.J., Mohtasham J., Holcomb N.R., Grainger D.W., Graham D., Castner D.G., Gard G.L., J. Fluorine Chem., 2002, 115, 107-113.

(25) Nixon, P.G.; Winter, R.; Castner, D.G.; Holcomb, N.R.; Grainger ,D.W.; Gard, G.L. Chem. Mater., 2000, 12, 3108-3112.

(26) In-house work at Portland State University.

(27) St. Clair, T.L.; St. Clair, A.K. ; Thrasher, J.S. US Patent 5,220,070, 1993.

(28) Winter, R.W.; Winner ,S.W.; Preston ,D.A.; Mohtasham, J.; Smith ,J.A.; Gard, G.L, J. Fluorine Chem., 2002, 115, 101-109.

(29) Geiser, U.; Schlueter, J.A.; Wang, H.H.; Kini, A.M.; Sche, P.P.; Zakowicz ,H.I.; Winter, R.W.; Gard ,G.L. J. Amer. Chem. Soc., 1996, 118, 9996-9998.

(30) Geiser, U.; Schlueter, J.A.; Kini, A.M.; Wang ,H.H.; Ward, B.H.; Whited, M.A.; Mohtasham, J.; Gard, G.L. Synthet. Met., 2003, 133-134, 401-411.

(31) Singh, R.P.; Winter R.W.; Gard, G.L.; Gao ,Y.; Shreeve, J.M. Inorg. Chem., 2003, 42, 6142-6149.

(32) Smith, J.; Di Stasio, R.A.; Hannah ,N.; Rananavare, S.B.; Weakley, T.; Winter, R.W.; Gard, G.L. J. Physical Chem., 2004, 42, 114-121.

(33) Banks, R.E.; Haszeldine, R.N. Brit.Patent 1,145,263 1969.

(34) Banks, R.E.; Barlow, M.G.; Haszeldine, R.N.; Morton, W.D. J. Chem. Soc., Perkin I, 1974, 12661271.

(35) Wessel, J.; Kleeman, G.; Seppelt, K., Chem. Ber., 1983, 116, 2399-2407.

(36) De Marco, R. A.; Fox, W. B. J. Fluorine Chem., 1978, 12, 137-151.

(37) Winter, R.; Gard, G.L. Inorg. Chem., 1988, 27, 4329-4331.

(38) Mohtasham, J.; Terjeson, R. J.; Gard, G. L.; Scott, R. A.; Madappat, K. V.; Thrasher, J. S. Inorg. Synth., 1992, 29, 33-38.

(39) Ait-Mohand,S.; Dolbier, W.R. Org. Lett., 2002, 4,(17), 3013-3015

(40) Case, J.R.; Ray, N.H.; Roberts, H.L. J. Chem. Soc. 1961, 2070-2075.

(41) a) Pianca, M.; Bonardelli, P.; Tato, M.; Cirillo, G.; Moggi, G. Polymer 1987, 28, 224-230; b)

Souzy, R,; Ameduri,B.; Arguello, G.; Willner, H. J. Fluorine Chem. 2003, 123, 85-93.

(42) Otazaghine,B.; Sauguet,L.; Boucher, M.; Ameduri, B. Eur. Polym. J. (in press) (2005)

(43) a) Russo, S.; Behari, K.; Chengji, S.; Pianca, M.; Barchiesi, E.; Moggi, G. Polymer 1993, 34 , 4777-4785; b) Duc, M.; Ameduri, B.; Boutevin, B.; Kharroubi, M.; Sage, J.M. Macromol. Chem. Phys, 
1998, 199, 1271-1288.; c) Pianca, M.; Barchiesi, E.; Espoto, G.; Radice, S. J. Fluorine Chem. 1999, 95, 71-85; d) Guiot, J.; Ameduri, B.; Boutevin, B. Macromolecules 2002, 35, 8694-8707.

(44) Souzy, R.; Ameduri, B.; Boutevin, B. J. Polym. Sc. Part A Polym. Chem. 2004, 42, 5077-5097.

.(45) Balague, J.; Ameduri, B.; Boutevin, B.; Caporiccio ,G. J. Fluorine Chem., 1995, 74, 49-58.

(46) Souzy, R.; Ameduri, B.; Boutevin, B.; Gebel ,G.; Capron, P. Fuel Cells (in press) 2005.

(47) Muller, N.; Lantebur, P.C.; Svatos, G.F. J. Amer. Chem. Soc., 1957, 79, 1044-1049

(48) Cross ,L.H.; Cushing, G.; Roberts, H.L. Spectrochim. Acta, 1961, 17, 344-352.

(49) Usmanov, K.U.; Yul'chibaev, A.A.; Mukhamadaliev, N.; Sarros ,T.K. Khim.Khim. Tekchol. 1975, $18,464-6$.

(50) Otazaghine, B.;Sauguet, L; Boucher, M.;Ameduri, B.Eur. Polym. J. 2005,41(8), 1747-1756. 


\section{FIGURE CAPTIONS}

Fig. $1{ }^{19} \mathrm{~F}$ NMR spectrum of $\mathrm{VDF} / \mathrm{CF}_{2}=\mathrm{CF}\left(\mathrm{SF}_{5}\right)$ copolymer at $70 / 30 \mathrm{~mol} \%$ monomer ratio in the feed

Fig. $2{ }^{1} \mathrm{H}$ NMR spectrum of $\mathrm{VDF} / \mathrm{CF}_{2}=\mathrm{CF}\left(\mathrm{SF}_{5}\right)$ copolymer at $70 / 30 \mathrm{~mol} \%$ monomer ratio in the feed

Fig. 3 Radical terpolymerizations of $\mathrm{SF}_{5}$ monomers with VDF and HFP.

Fig. $4{ }^{19}$ F NMR spectrum of VDF/HFP/SF 5 (M-I) terpolymer at initial monomer ratio in the feed $=72.0 / 19.4 / 8.6 \mathrm{~mol} \%$

Fig $.5{ }^{1} \mathrm{H}$ NMR spectrum of $\mathrm{VDF} / \mathrm{HFP} / \mathrm{SF}_{5}(\mathrm{M}-\mathrm{I})$ terpolymer I at initial monomer ratio in the feed $=72.0 / 19.4 / 8.6 \mathrm{~mol} \%$

Fig. $6{ }^{19} \mathrm{~F}$ NMR spectrum of $\mathrm{VDF} / \mathrm{HFP} / \mathrm{SF}_{5}(\mathrm{M}-\mathrm{III})$ terpolymer III recorded in deuterated acetone at initial monomer ratio $73.1 / 18.3 / 8.6 \mathrm{~mol} \%$

Fig. $7{ }^{1} \mathrm{H}$ NMR spectrum of $\mathrm{VDF} / \mathrm{HFP} / \mathrm{SF}_{5}(\mathrm{M}-\mathrm{III})$ terpolymer III recorded in deuterated acetone at initial monomer ratio $73.1 / 18.3 / 8.6 \mathrm{~mol} \%$

Fig. 8 SEC Chromatograms of poly(VDF-ter-HFP-ter-SF 5 M) terpolymers. Terpolymer compositions of $\mathrm{VDF} / \mathrm{HFP} / \mathrm{SF}_{5} \mathrm{M}$ in mol \% :I -71.0/11.6/17.4 ;II- 83.8/14.1/2.1; III - 78.3/16.4/5.3; IV $78.1 / 13.5 / 8.3$

Fig.9 Thermogravimetric curves of $\mathrm{VDF} / \mathrm{HFP} / \mathrm{SF}_{5} \mathrm{M}$ terpolymers in air of $\mathrm{VDF} / \mathrm{HFP} / \mathrm{SF}_{5}$ terpolymers. Terpolymer compositions of $\mathrm{VDF} / \mathrm{HFP} / \mathrm{SF}_{5} \mathrm{M}$ in $\mathrm{mol} \%$ :I -71.0/11.6/17.4 ;II83.8/14.1/2.1; III - 78.3/16.4/5.3; IV - 78.1/13.5/8.3 


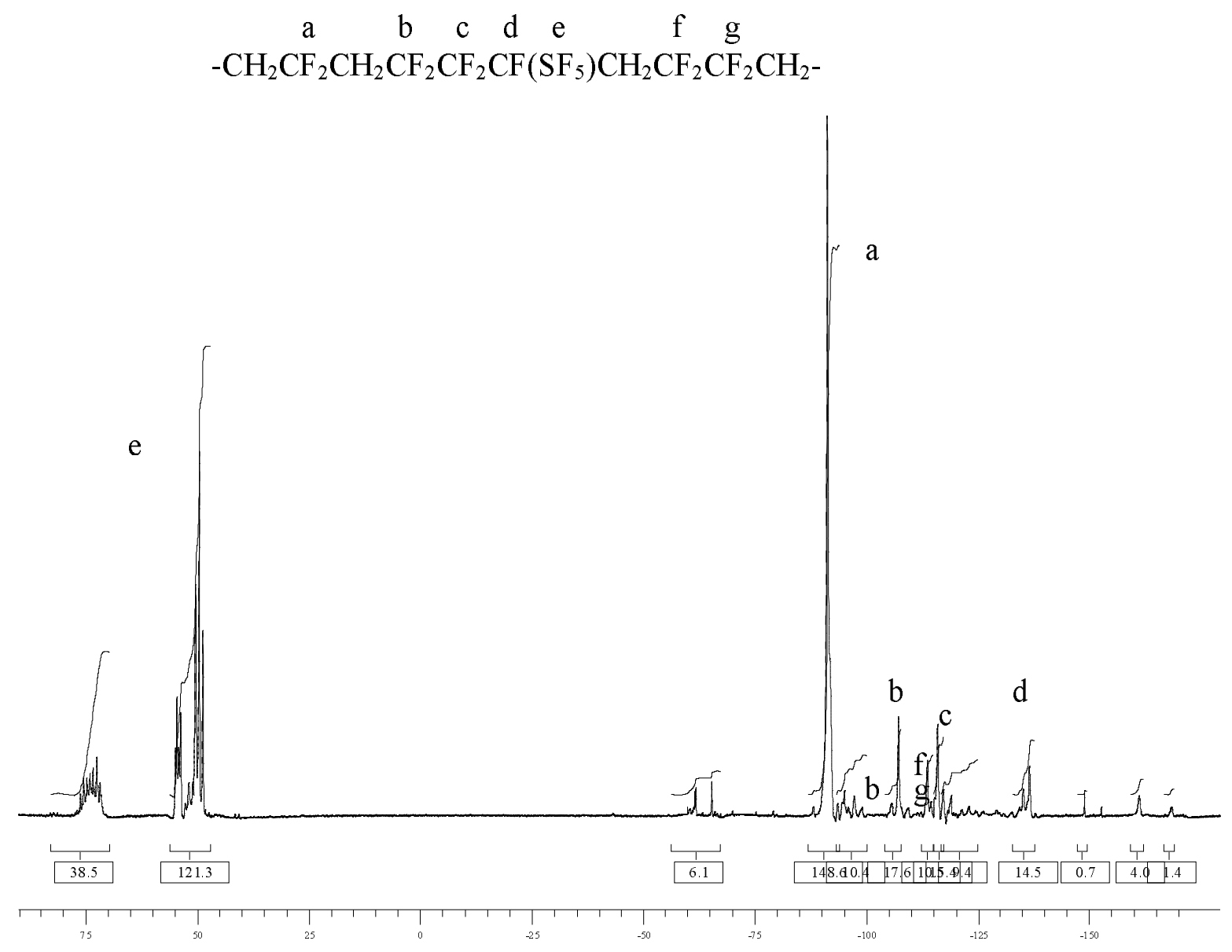

Fig. $1{ }^{19} \mathrm{~F}$ NMR spectrum of $\mathrm{VDF} / \mathrm{CF}_{2}=\mathrm{CF}\left(\mathrm{SF}_{5}\right)$ copolymer at $70 / 30 \mathrm{~mol} \%$ monomer ratio in the feed 
a

b c

$-\mathrm{CH}_{2} \mathrm{CF}_{2} \mathrm{CH}_{2} \mathrm{CF}_{2} \mathrm{CF}_{2} \mathrm{CF}\left(\mathrm{SF}_{5}\right) \mathrm{CF}_{2} \mathrm{CH}_{2} \mathrm{CH}_{2} \mathrm{CF}_{2}-$

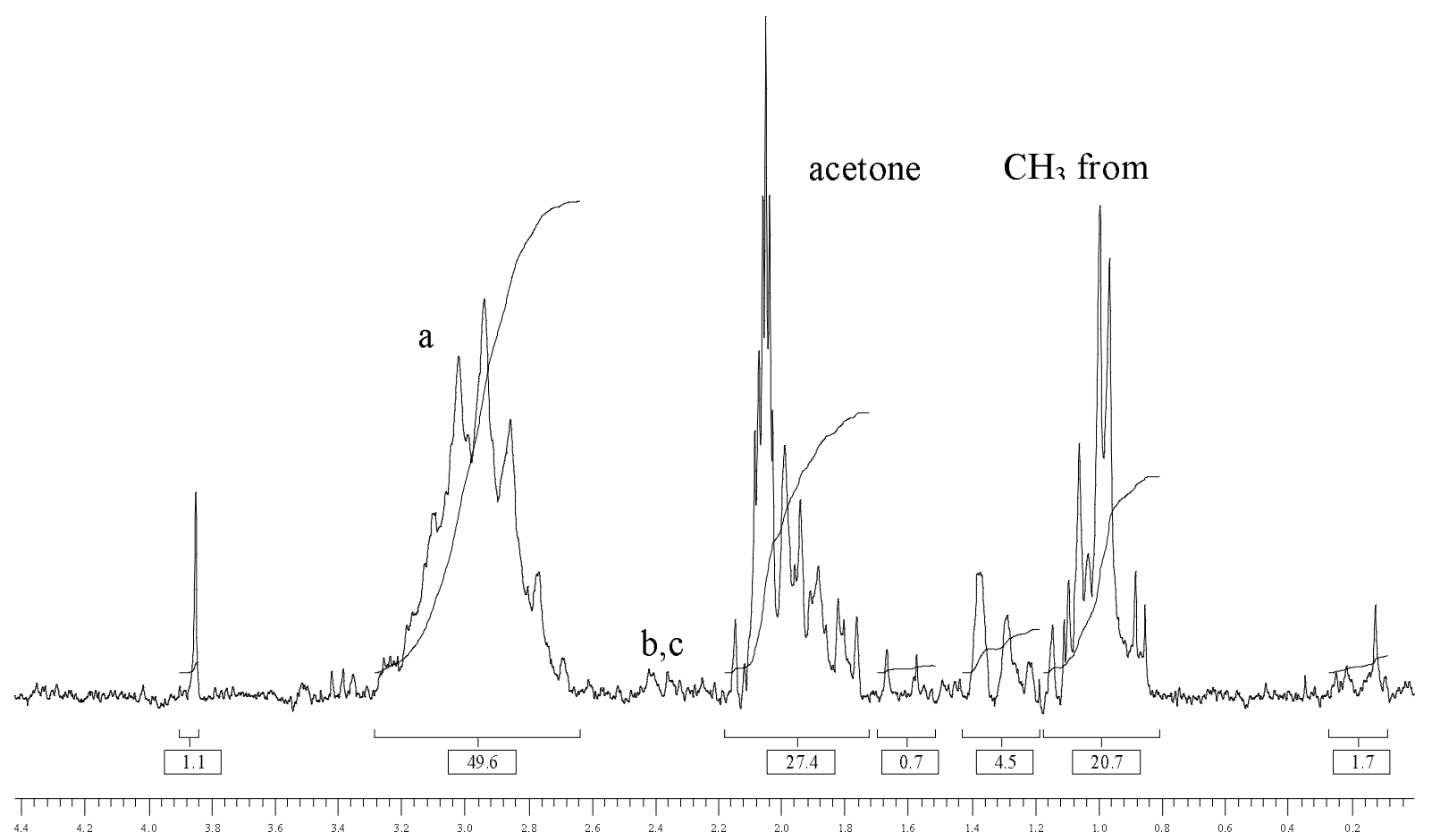

Fig. $2{ }^{1} \mathrm{H}$ NMR spectrum of $\mathrm{VDF} / \mathrm{CF}_{2}=\mathrm{CF}\left(\mathrm{SF}_{5}\right)$ copolymer at $70 / 30 \mathrm{~mol} \%$ monomer ratio in the feed 
Fig. 3: Radical terpolymerization of $\mathrm{SF}_{5}$ monomers with VDF and HFP.

$$
\begin{aligned}
& \mathrm{nH}_{2} \mathrm{C}=\mathrm{CF}_{2}+\mathrm{mF}_{2} \mathrm{C}=\mathrm{CFCF}_{3}+\mathrm{pXCY}=\mathrm{CZSF}_{5} \stackrel{\text { radica }}{\longrightarrow}\left[\left(\mathrm{CH}_{2} \mathrm{CF}_{2}\right)_{\mathrm{t}}-\left(\mathrm{CF}_{2} \mathrm{CF}\right)_{\mathrm{u}}-(\mathrm{CXYCZ})_{v}\right]_{q} \\
& \mathrm{CF}_{3} \quad \mathrm{SF}_{5}
\end{aligned}
$$


$\begin{array}{lllllllllll}\text { a } & b & c & d & \text { e } & f & g & h & \text { i }\end{array}$

\section{$-\mathrm{CH}_{2} \mathrm{CF}_{2} \mathrm{CH}_{2} \mathrm{CF}_{2} \mathrm{CF}_{2} \mathrm{CF}\left(\mathrm{CF}_{3}\right) \mathrm{CH}_{2} \mathrm{CF}_{2} \mathrm{CH}_{2} \mathrm{CH}\left(\mathrm{SF}_{5}\right) \mathrm{CH}_{2} \mathrm{CF}_{2} \mathrm{CF}_{2} \mathrm{CH}_{2}-$}
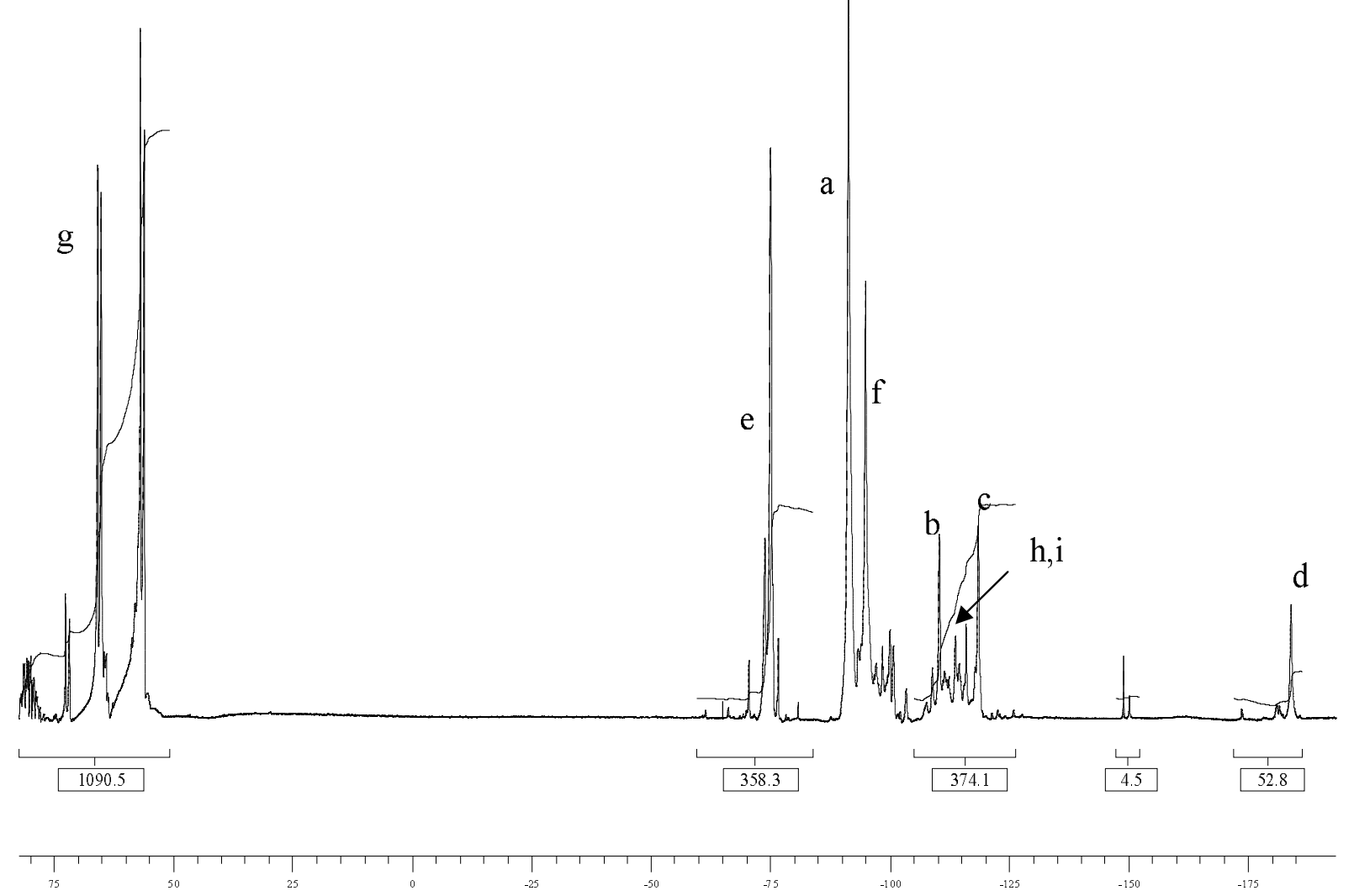

Fig. $4{ }^{19} \mathrm{~F}$ NMR spectrum of $\mathrm{VDF} / \mathrm{HFP} / \mathrm{SF}_{5}(\mathrm{M}-\mathrm{I})$ terpolymer I at initial monomer ratio in the feed $=72.0 / 19.4 / 8.6 \mathrm{~mol} \%$ 
a

$-\mathrm{CH}_{2} \mathrm{CF}_{2} \mathrm{CH}_{2} \mathrm{CF}_{2} \mathrm{CF}_{2} \mathrm{CF}\left(\mathrm{CF}_{3}\right) \mathrm{CH}_{2} \mathrm{CF}_{2} \mathrm{CH}_{2} \mathrm{CH}\left(\mathrm{SF}_{5}\right) \mathrm{CF}_{2} \mathrm{CH}_{2} \mathrm{CH}_{2} \mathrm{CF}_{2}-$

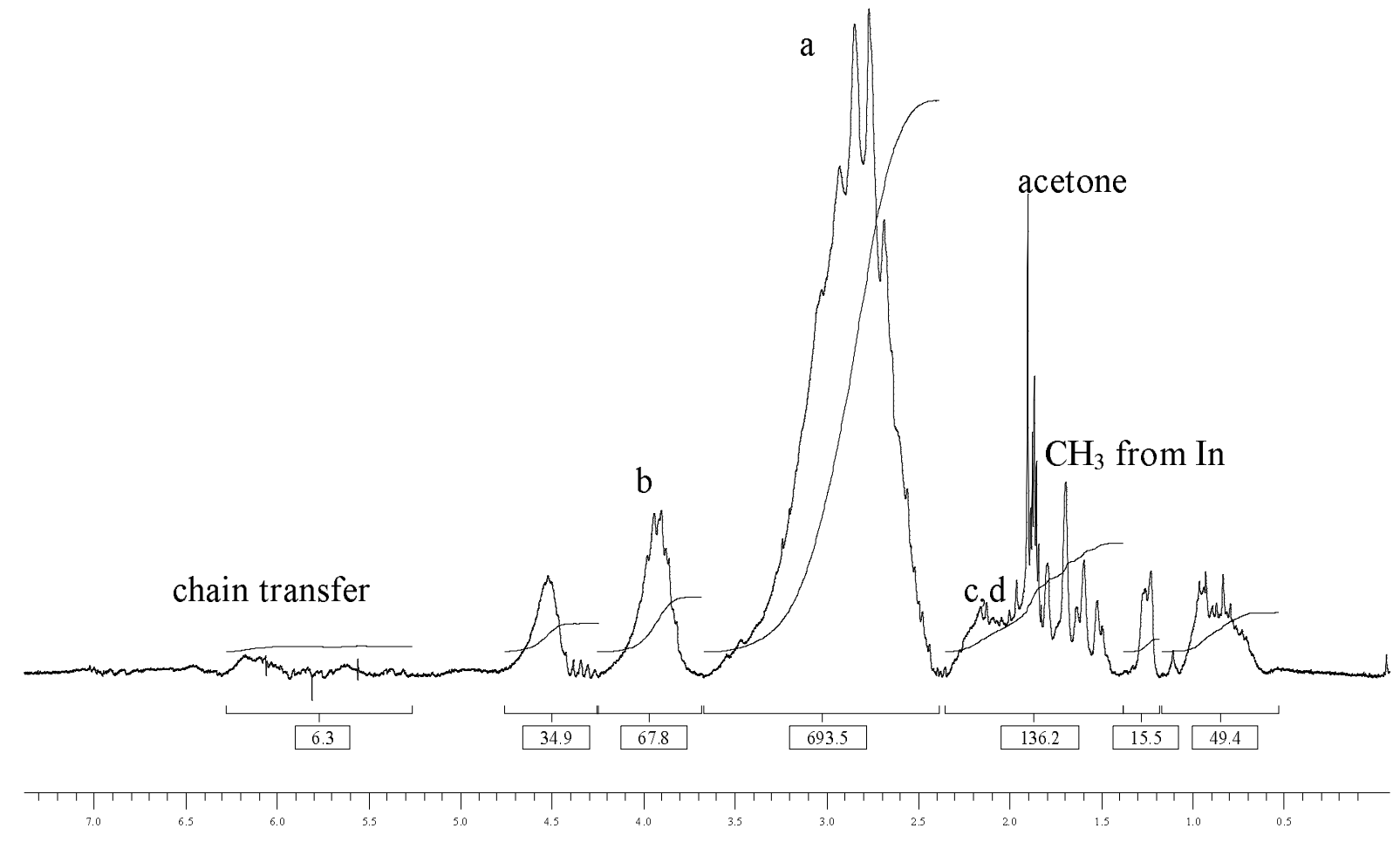

Fig $.5{ }^{1} \mathrm{H}$ NMR spectrum of VDF/HFP/SF 5 (M-I) terpolymer I at initial monomer ratio in the feed $=72.0 / 19.4 / 8.6 \mathrm{~mol} \%$ 


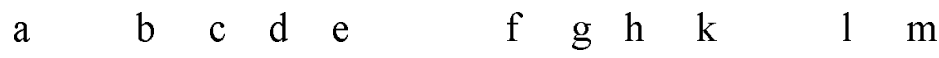
$-\mathrm{CH}_{2} \mathrm{CF}_{2} \mathrm{CH}_{2} \mathrm{CF}_{2} \mathrm{CF}_{2} \mathrm{CF}\left(\mathrm{CF}_{3}\right) \mathrm{CH}_{2} \mathrm{CF}_{2} \mathrm{CF}_{2} \mathrm{CF}\left(\mathrm{SF}_{5}\right) \mathrm{CH}_{2} \mathrm{CF}_{2} \mathrm{CF}_{2} \mathrm{CH}_{2}-$

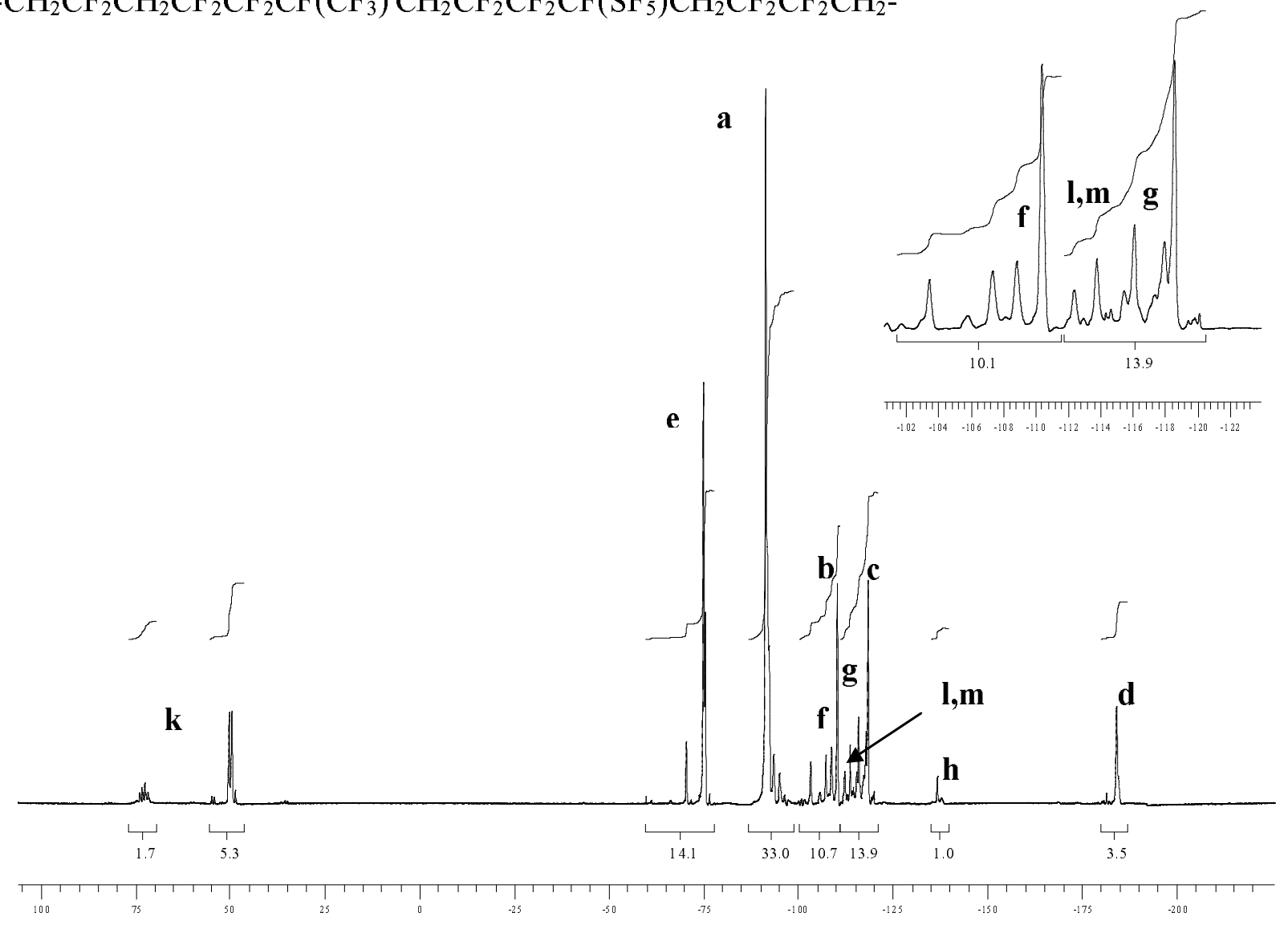

Fig. $6{ }^{19} \mathrm{~F}$ NMR spectrum of $\mathrm{VDF} / \mathrm{HFP} / \mathrm{SF}_{5}(\mathrm{M}-\mathrm{III})$ terpolymer III recorded in deuterated acetone at initial monomer ratio $73.1 / 18.3 / 8.6 \mathrm{~mol} \%$ 


\section{a $-\mathrm{CH}_{2} \mathrm{CF}_{2} \mathrm{CH}_{2} \mathrm{CF}_{2} \mathrm{CF}_{2} \mathrm{CF}(\mathrm{CF})_{3} \mathrm{CH}_{2} \mathrm{CF}_{2} \mathrm{CF}_{2} \mathrm{CF}\left(\mathrm{SF}_{5}\right) \mathrm{CF}_{2} \mathrm{CH}_{2} \mathrm{CH}_{2} \mathrm{CF}_{2}-$}

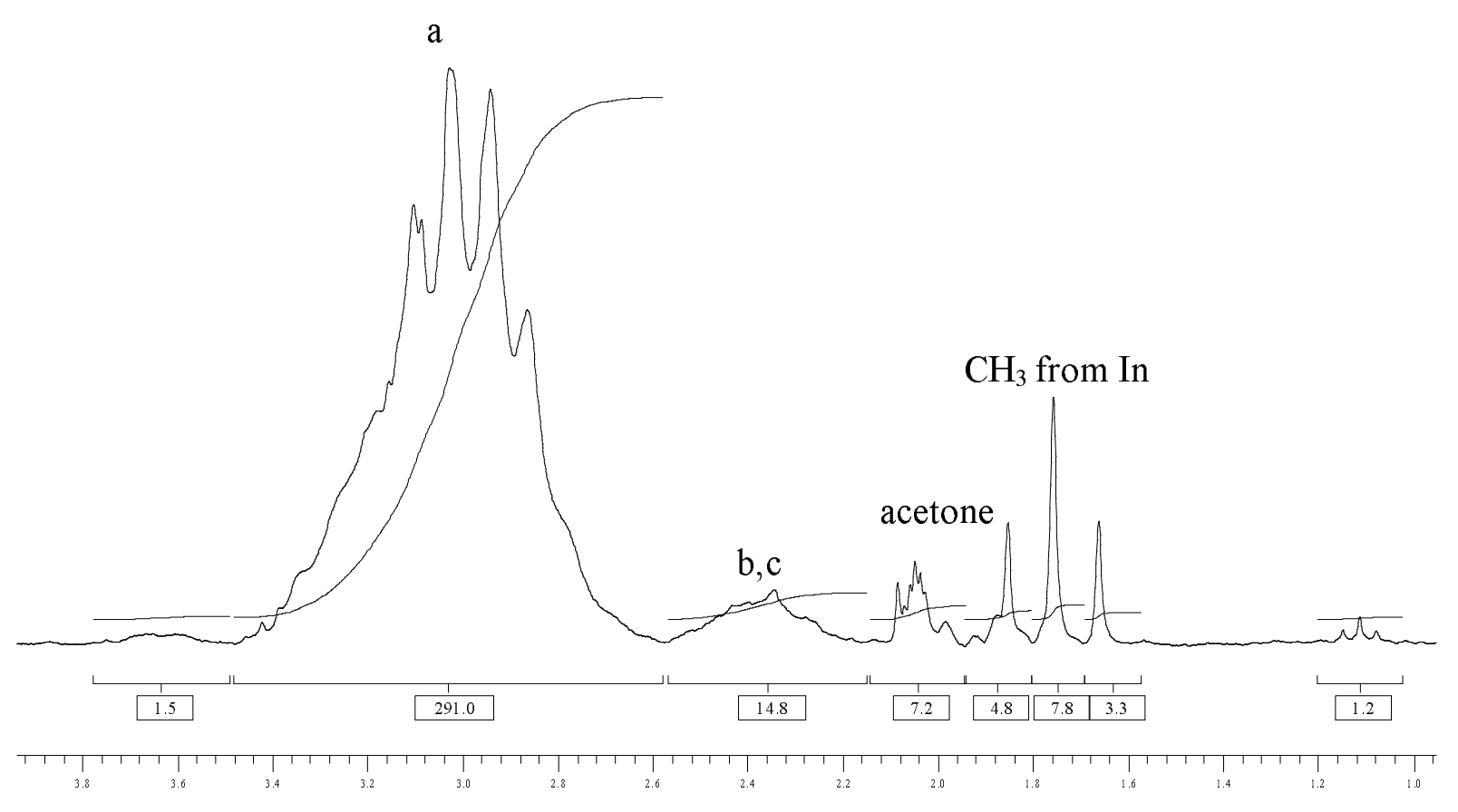

Fig. $7{ }^{1} \mathrm{H}$ NMR spectrum of VDF/HFP/SF5(M-III) terpolymer III recorded in deuterated acetone at initial monomer ratio $73.1 / 18.3 / 8.6 \mathrm{~mol} \%$ 


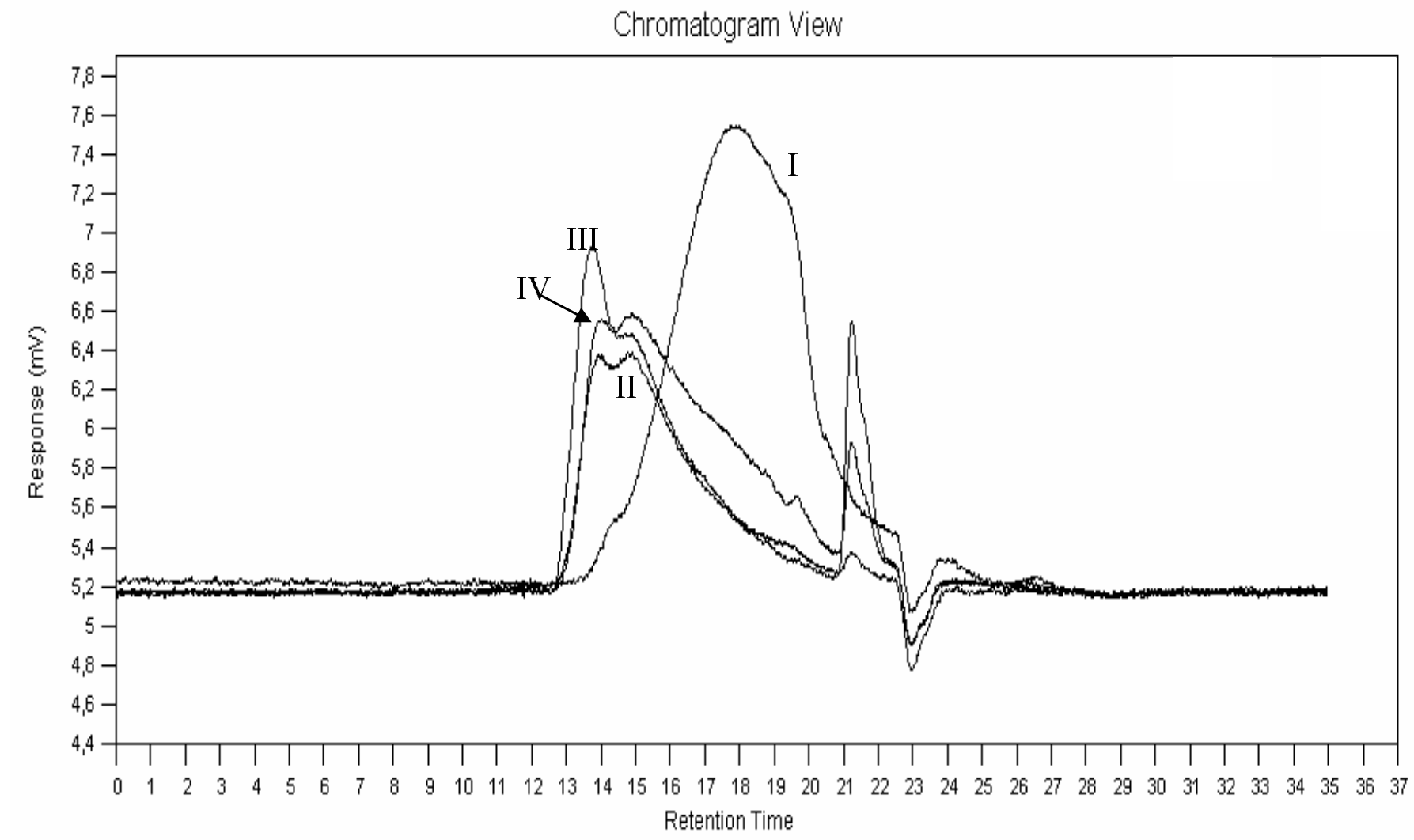

Fig. 8 SEC Chromatograms of poly(VDF-ter-HFP-ter-SF $\left.{ }_{5} \mathrm{M}\right)$ terpolymers. Terpolymer compositions of $\mathrm{VDF} / \mathrm{HFP} / \mathrm{SF}_{5} \mathrm{M}$ in mol \% :I -71.0/11.6/17.4 ;II- 83.8/14.1/2.1; III - 78.3/16.4/5.3; IV $78.1 / 13.5 / 8.3$ 


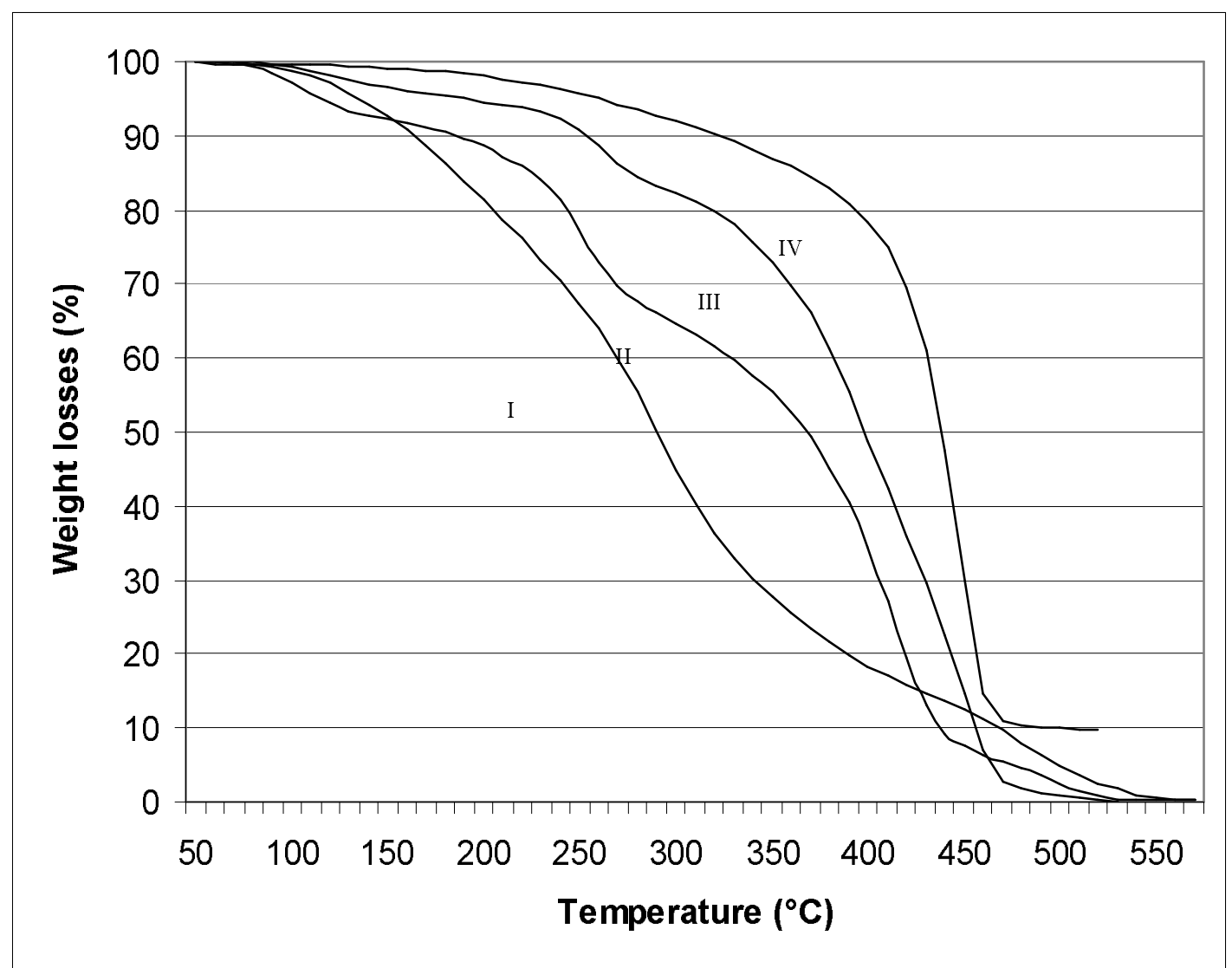

Fig.9 Thermogravimetric curves of $\mathrm{VDF} / \mathrm{HFP} / \mathrm{SF}_{5} \mathrm{M}$ terpolymers in air of $\mathrm{VDF} / \mathrm{HFP} / \mathrm{SF}_{5}$ terpolymers. Terpolymer compositions of $\mathrm{VDF} / \mathrm{HFP} / \mathrm{SF}_{5} \mathrm{M}$ in $\mathrm{mol} \%$ :I -71.0/11.6/17.4 ;II83.8/14.1/2.1; III - 78.3/16.4/5.3; IV - 78.1/13.5/8.3 


\section{TABLE CAPTIONS}

Table 1: Comparative study of different reactivities of VDF with various monomers ${ }^{\mathrm{a}}$ :HFP, PMVE, PPVE, $\mathrm{CF}_{2}=\mathrm{CFSF}_{5}$

Table 2. ${ }^{19}$ F-NMR assignments of fluorinated groups in the poly(VDF-ter-HFP-ter- $\mathrm{SF}_{5} \mathrm{M}$ ) terpolymers recorded in deuterated acetone.

Table 3: Molecular weights of poly(VDF-co-SF 5 MIII) and poly(VDF-ter-HFP-ter-SF $\left.{ }_{5} \mathrm{Mi}\right)$ copolymers assessed by ${ }^{1} \mathrm{H}$ and ${ }^{19} \mathrm{~F}$ NMR analyses

Table 4: $\quad$ Monomer - polymer compositions of poly(VDF-ter-HFP-ter-SF 5 M) terpolymers and their main characteristics. Reaction conditions: initiator DTBP -1 mol \%; solvent pentafluorobutane $-70 \mathrm{wt} \% ; 143{ }^{0} \mathrm{C} ; 5 \mathrm{hrs}$. 
Table 1.Comparative study of different reactivities of VDF with various monomers in radical copolymerization $^{\mathrm{a}}$

\begin{tabular}{|c|c|c|c|c|c|c|c|c|c|c|}
\hline \multirow{2}{*}{$\begin{array}{l}\text { Run } \\
\text { No }\end{array}$} & \multicolumn{5}{|c|}{ Mol \% monomer in the feed } & \multicolumn{5}{|c|}{ Mol \% monomer in the copolymer } \\
\hline & VDF & HFP & PMVE & PPVE & $-\mathrm{SF}_{5}$ & VDF & HFP & PMVE & PPVE & $-\mathrm{SF}_{5}$ \\
\hline 1 & 21.6 & 78.4 & - & - & - & 53.4 & 46.6 & - & - & - \\
\hline 2 & 49.5 & 50.5 & - & - & - & 78.1 & 21.9 & - & - & - \\
\hline 3 & 75.0 & 25.0 & - & - & - & 89.3 & 10.7 & - & - & - \\
\hline & & & & & & & & & & \\
\hline 4 & 20.0 & - & 80.0 & - & - & 61.8 & - & 38.2 & - & - \\
\hline 5 & 50.8 & - & 49.2 & - & - & 73.6 & - & 26.4 & - & - \\
\hline 6 & 78.9 & - & 21.1 & - & - & 85.5 & - & 14.5 & - & - \\
\hline & & & & & & & & & & \\
\hline 7 & 20.4 & - & - & 79.6 & - & 57.0 & - & - & 43.0 & - \\
\hline 8 & 50.1 & - & - & 49.9 & - & 73.0 & - & - & 27.0 & - \\
\hline 9 & 70.1 & - & - & 29.9 & - & 74.6 & - & - & 25.4 & - \\
\hline & & & & & & & & & & \\
\hline 10 & 20.0 & - & - & - & 80.0 & 81.2 & - & - & - & 18.8 \\
\hline 11 & 49.6 & - & - & - & 50.4 & 83.6 & - & - & - & 16.4 \\
\hline 12 & 69.8 & - & - & - & 30.2 & 86.4 & - & - & - & 13.6 \\
\hline
\end{tabular}

a) no homopolymerization of $\mathrm{CF}_{2}=\mathrm{CFSF}_{5}$ monomer 
Table 2: $\quad{ }^{19} \mathrm{~F}-\mathrm{NMR}$ assignments of fluorinated groups in the poly(VDF-ter-HFP-ter- $\mathrm{CF}_{2}=\mathrm{CFSF}_{5}$ ) terpolymers recorded in deuterated acetone.

\begin{tabular}{ccc}
\hline $\begin{array}{c}\text { Chemical shift } \\
(\mathrm{ppm})\end{array}$ & structure & $\begin{array}{c}\text { Integrals in Eq } \\
1,3\end{array}$ \\
\hline-71.2 & $-\mathrm{CH}_{2} \mathrm{CF}_{2} \mathrm{CF}_{2} \mathrm{CF}\left(\mathrm{CF}_{3}\right)-\mathrm{CF}_{2}-\mathrm{CH}_{2}-$ & $\mathrm{I}_{-71.2}$ \\
-74.8 & $-\mathrm{CH}_{2}-\mathrm{CF}_{2}-\mathrm{CF}_{2}-\mathrm{CF}\left(\mathrm{CF}_{3}\right)-\mathrm{CH}_{2}-\mathrm{CF}_{2}-$ & $\mathrm{I}_{-74.8}$ \\
-91.1 & $-\mathrm{CF}_{2}-\mathrm{CH}_{2}-\mathrm{CF}_{2}-\mathrm{CH}_{2}-\mathrm{CF}_{2}-$ & \\
-94.9 & $\left(\mathrm{CH}_{2}-\mathrm{CF}_{2}\right)-\left(\mathrm{CF}_{2}-\mathrm{CH}_{2}\right)-\left(\mathrm{CH}_{2}-\mathrm{CF}_{2}\right)-\left(\mathrm{CH}_{2}-\mathrm{CF}_{2}\right)$ & $\mathrm{I}_{-94.9}$ \\
-108 & $-\mathrm{CH}_{2} \mathrm{CF}_{2} \mathrm{CF}_{2} \mathrm{CF}_{2}\left(\mathrm{SF}_{5}\right)-$ & $\mathrm{I}_{-108}$ \\
-110.1 & $-\left(\mathrm{CH}_{2}-\mathrm{CF}_{2}\right) \mathrm{CF}_{2} \mathrm{CF}_{(-1}\left(\mathrm{CF}_{3}\right)-$ & $\mathrm{I}_{-110.1}$ \\
-113.7 & $-\left(\mathrm{CH}_{2}-\mathrm{CF}_{2}\right)-\left(\mathrm{CF}_{2}-\mathrm{CH}_{2}\right)-\left(\mathrm{CF}_{2}-\mathrm{CH}_{2}\right)-$ & $\mathrm{I}_{-113.7}$ \\
-113.8 & $-\mathrm{CF}_{2} \mathrm{CH}_{2}\left(\mathrm{CH}_{2}-\mathrm{CF}_{2}\right)-\left[\mathrm{CF}_{2}-\mathrm{CH}_{2}\right]-$ & $\mathrm{I}_{-113.8}$ \\
-115.7 & $-\left(\mathrm{CH}_{2}-\mathrm{CF}_{2}\right)-\left(\mathrm{CF}_{2}-\mathrm{CH}_{2}\right)-\left(\mathrm{CH}_{2}-\mathrm{CF}_{2}\right)-$ & $\mathrm{I}_{115.7}$ \\
-118.8 & $-\mathrm{CH}_{2} \mathrm{CF}_{2} \mathrm{CF}_{2} \mathrm{CF}\left(\mathrm{SF}_{5}\right)-$ & $\mathrm{I}_{-118.8}$ \\
-136.7 & $-\left(\mathrm{CH}_{2}-\mathrm{CF}_{2}\right)-\left[\mathrm{CF}_{2}-\mathrm{CFSF}_{5}\right]-$ & $\mathrm{I}_{-136.7}$ \\
-183.5 & $-\mathrm{CH}_{2} \mathrm{CF}_{2} \mathrm{CF}_{2} \mathrm{CF}_{-183.5}\left(\mathrm{CF}_{3}\right)-$ & \\
\hline
\end{tabular}


Table 3. Molecular weights of poly(VDF-co-SF 5 MIII) and poly (VDF-ter-HFP-ter-SF ${ }_{5} \mathrm{Mi}$ ) copolymers assessed by ${ }^{1} \mathrm{H}$ and ${ }^{19} \mathrm{~F}$ NMR analyses

\begin{tabular}{|c|c|c|c|c|c|c|c|c|}
\hline \multirow{2}{*}{ Exp. $\mathrm{No}^{\mathrm{a}}$} & \multicolumn{3}{|c|}{ Feed, mol \% } & \multirow{2}{*}{$\mathrm{N}_{\mathrm{VDF}}$} & \multicolumn{3}{|c|}{ Molar ration in copolymers ${ }^{b}$} & \multirow{2}{*}{$\begin{array}{c}\mathrm{Mn} \\
\mathrm{g} / \mathrm{mol}\end{array}$} \\
\hline & VDF & $\mathrm{SF}_{5} \mathrm{Mi}$ & HFP & & $\alpha$ & $\alpha_{1}$ & $\alpha_{2}$ & \\
\hline 1 & 20.0 & 80.0 & - & 15 & 0.23 & - & - & 1750 \\
\hline 2 & 49.6 & 50.4 & - & 16 & 0.20 & - & - & 1740 \\
\hline 3 & 69.8 & 30.2 & - & 55 & 0.16 & - & - & 5350 \\
\hline 4 & 72.0 & 8.6 & 19.4 & 35 & - & 0.16 & 0.25 & 4900 \\
\hline 5 & 75.2 & 8.7 & 16.1 & 130 & - & 0.17 & 0.03 & 12400 \\
\hline 6 & 73.1 & 8.6 & 18.3 & 154 & - & 0.21 & 0.07 & 16900 \\
\hline 7 & 71.1 & 13.6 & 15.3 & 65 & - & 0.17 & 0.11 & 7300 \\
\hline
\end{tabular}

a) Experiments No 1 to 3 concern Run No 10-12 in Table 1 ; Experiments No 4 to 7 concern Exp. numbers in Table 4

b) $\alpha=\mathrm{mol}_{\%} \mathrm{SF}_{5} \mathrm{MIII} / \mathrm{mol} \% \mathrm{VDF}$ in copolymer, $\alpha_{1}=\% \mathrm{HFP} / \mathrm{mol} \% \mathrm{VDF}$ in terpolymer ; $\alpha_{2}=\mathrm{mol}_{\%} \mathrm{SF}_{5} \mathrm{Mi} / \mathrm{mol} \% \mathrm{VDF}$ in terpolymer 
Table 4. Monomer - polymer compositions of poly(VDF-ter-HFP-ter-SF 5 M) terpolymers and their main characteristics. Reaction conditions : initiator DTBP $-1 \mathrm{~mol} \%$; solvent pentafluorobutane -70 wt $\% ; 143{ }^{0} \mathrm{C} ; 5 \mathrm{~h}$

\begin{tabular}{|c|c|c|c|c|c|c|c|c|c|c|}
\hline \multirow[t]{2}{*}{$\begin{array}{l}\text { Exp No } \\
\text { Monomer }\end{array}$} & \multicolumn{3}{|c|}{$\begin{array}{c}\text { Feed } \\
(\mathrm{mol} \%)\end{array}$} & \multicolumn{3}{|c|}{$\begin{array}{c}\text { Terpo } \\
(\mathrm{mol} \%)\end{array}$} & \multirow{2}{*}{$\begin{array}{l}Y \\
\text { (wt } \\
\% \text { ) }\end{array}$} & \multirow[t]{2}{*}{$\begin{array}{c}\mathrm{Mn} \\
(\mathrm{g} / \mathrm{mol})\end{array}$} & \multirow[t]{2}{*}{ PDI } & \multirow[t]{2}{*}{$\begin{array}{l}\mathrm{Tg} \\
\left({ }^{0} \mathrm{C}\right)\end{array}$} \\
\hline & VDF & HFP & $\mathrm{SF}_{5} \mathrm{M}$ & VDF & HFP & $\mathrm{SF}_{5} \mathrm{M}$ & & & & \\
\hline $\begin{array}{c}\text { Polymer I* } \\
\mathrm{H}_{2} \mathrm{C}=\mathrm{CH}\left(\mathrm{SF}_{5}\right)\end{array}$ & 72.0 & 19.4 & 8.6 & 71.0 & 11.6 & 17.4 & 45.0 & 2540 & 2.0 & -50 \\
\hline $\begin{array}{c}\text { Polymer II* } \\
\mathrm{F}_{2} \mathrm{C}=\mathrm{CH}\left(\mathrm{SF}_{5}\right)\end{array}$ & 75.2 & 16.1 & 8.7 & 83.8 & 14.1 & 2.1 & 52.2 & 8290 & 2.3 & -41 \\
\hline $\begin{array}{l}\text { Polymer III* } \\
\mathrm{F}_{2} \mathrm{C}=\mathrm{CF}\left(\mathrm{SF}_{5}\right)\end{array}$ & 73.1 & 18.3 & 8.6 & 78.3 & 16.4 & 5.3 & 72.5 & 10030 & 2.4 & -40 \\
\hline $\begin{array}{l}\text { Polymer IV** } \\
\mathrm{F}_{2} \mathrm{C}=\mathrm{CF}\left(\mathrm{SF}_{5}\right)\end{array}$ & 71.1 & 15.3 & 13.6 & 78.1 & 13.5 & 8.3 & 91.2 & 6650 & 2.4 & -50 \\
\hline
\end{tabular}

*DTBP concentration $1 \mathrm{~mol} \%$

**DTBP concentration $3 \mathrm{~mol} \%$

Polymer solubility : soluble in acetone, THF, $\mathrm{C}_{4} \mathrm{~F}_{5} \mathrm{H}_{5}$; Polymers I and II not soluble in $\mathrm{CHCl}_{3}$ and $\mathrm{CH}_{2} \mathrm{Cl}_{2}$ whereas polymers III and IV are soluble in $\mathrm{CH}_{2} \mathrm{Cl}_{2}$ and partially in $\mathrm{CHCl}_{3}$ 